\title{
الإعلام الإسلامي: إشكالية المصطلح
}

\section{* علي سلطاني العاتري}

$$
\begin{aligned}
& \text { الملخص } \\
& \text { تمثّل العلوم الاجتماعية المعاصرة ذات المنشأ الغربي تحدياً للعلماء والباحثين المسلمين في جوانب متعددة، منها } \\
& \text { قضية المصطلح. ولمواجهة هذا التحدي جرت محاولات متعددة تحت عناوين مختلفة منها التأصيل والأسلمة. وواجهت } \\
& \text { هـذه المحاولات معارضـة شـديدة مـن دعـاة التمـاهي بـالفكر الغربي، مـن جهة، كما واجهـت نقـداً مـن داخل الدائرة } \\
& \text { الإسلامية نفسها من جهة أخرى، لما رآه الناقدون من مظاهر الخلل والقصور. وميدان الإعلام واحد من ميادين العلوم } \\
& \text { الاجتماعية التي لا يزال المصطلح فيها يمثل مشكلة في جهود التأصيل وبناء الرؤية الإسلامية. } \\
& \text { وقهدف هذه الدراسة إلى مناقشة مصطلح "الإعلام الإسلامي" ومـا يثيره مـ إشكالات معرفية، وانعكاسات } \\
& \text { تطبيقية، جعلت المصطلح قاصراً عن أداء الوظيفة المنشودة منه في بناء العلم وتوظيفه في تحقيق مقاصد الإسلام في } \\
& \text { البحتمع البشري المعاصر. } \\
& \text { الكلمات المفتاحية: الإعلام الإسلامي، المصطلح، الأسلمة، التأصيل }
\end{aligned}
$$

\section{Islamic media: A Terminology Issue}

Contemporary social science with its Western-origin represents a challenge for Muslim scholars and researchers in various aspects, including the issue of terminology. To meet this challenge various attempts have been made under different titles, such as Islamization and establishing Islamic foundations. Such attempts has faced stiff opposition from advocates of identification with Western thought, on the one hand, and criticism from within the Islamic Circle itself on the other hand, because of what was seen as imbalance and deficiencies. Media is one of the fields of social science, in which the terminology is still a problem in building Islamic perspective and establishing Islamic foundations of the field.

This study discusses the term "Islamic media", its epistemological problems, and practical implications; that makes the term unable to perform the desired function, especially in the construction of knowledge and using it to achieve Islamic objectives in the contemporary human society.

Key words: Islamic media, Term, Islamization, Islamic ta'sil: Establishing Islamic Foundation.

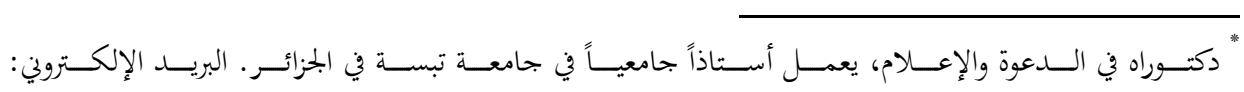

$$
\begin{aligned}
& \text { alielateri1@hotmail.com }
\end{aligned}
$$

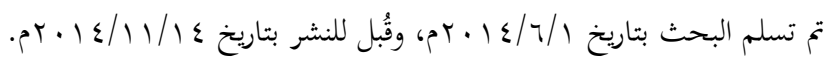




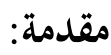

إن وقوع الباحثين العرب والمسلمين تحت تأثير المصطلحات والتصورات والأفكار الغربية جعلهم يعانون من تبعية فكرية، بل تبعية مصطلحية، ومن ثم يضطر كل باحث في

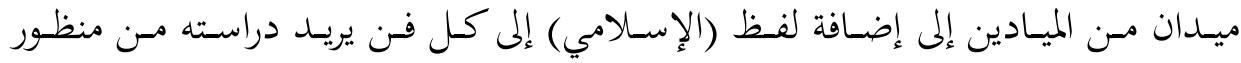
إسلامي؛ (كالإعلام الإسلامي) و(علم الاجتماع الإسلامي) و(علم النفس الإسلامي)،

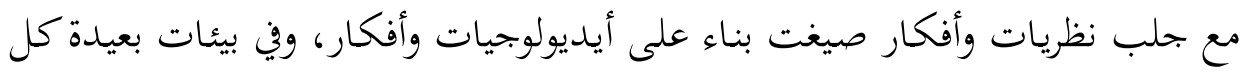

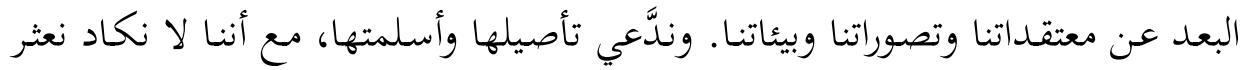

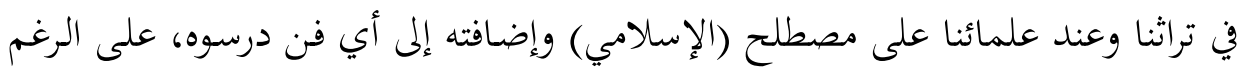

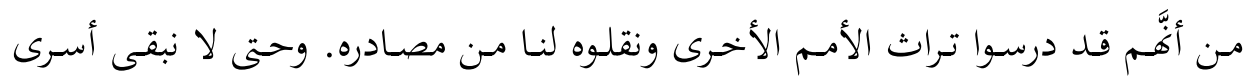

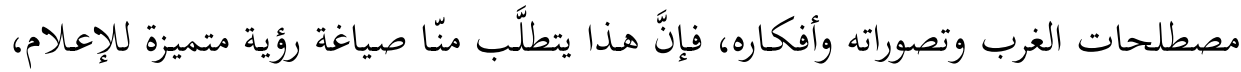

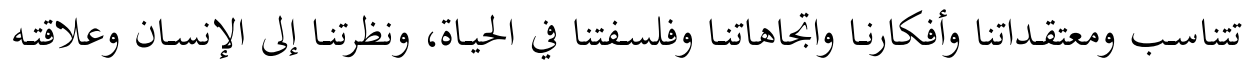
بالكون، وكذا علاقة كل من الإنسان والكون بخالقهما. وتمدف هذه الدراسة إلى مناقشة ما عرف بمصطلح الإعلام الإسلامي، وما يثيره من

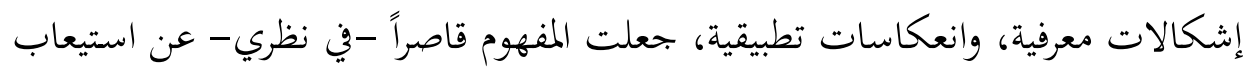

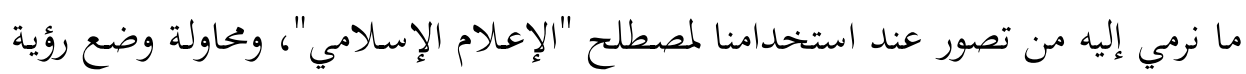

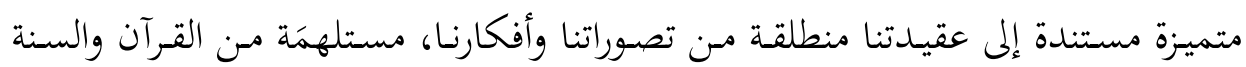

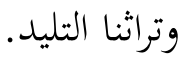

ووفقاً لمذا الطرح، سنحاول طرح إشكالية الإعلام الإسلامي؛ انطلاقاً من القرآن

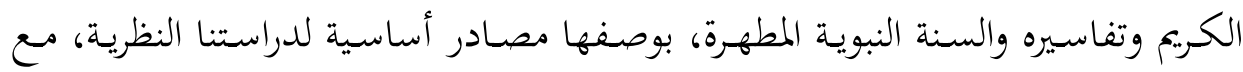

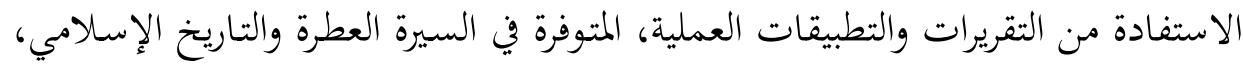

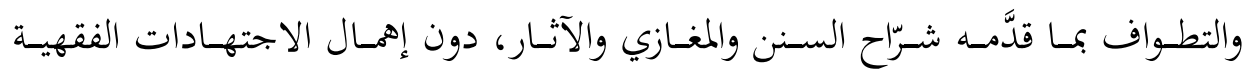

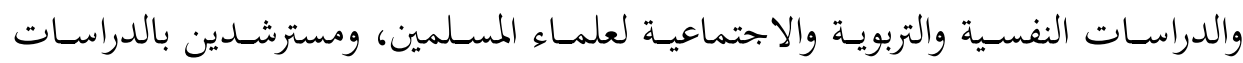

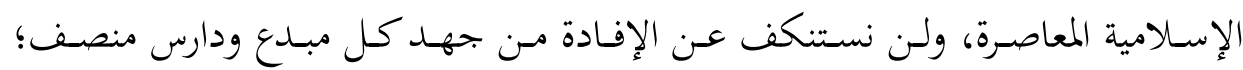

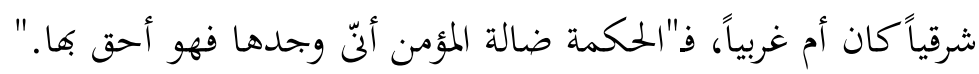


إن بحـالات الصــراع متعـددة وجوانبـه متشـعبة. ومسن أدوات الإعـاملام الصـراعية

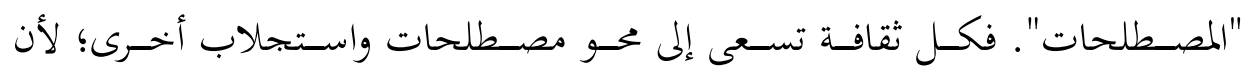
المصطلح هو الوعاء المعبّر عن المعتقدات والأفكار والناتج الحضاري، وقد صاحب ذلك الك

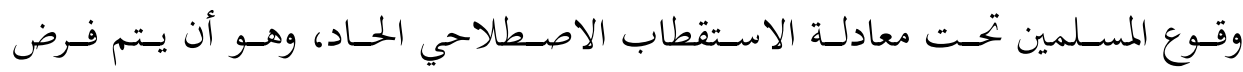
التصـورات التي يريـها الآخـر على العقليـة المسـلمة، مـن خهلال حتميـة وقوع المسـلم في طرين معادلة الاستقطاب؛ فمن لا يقرُّ بالتوظيف الغربي للمصطلح فهو بالضرورة رافض

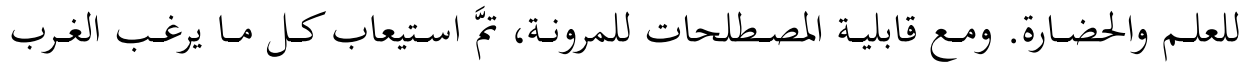
بإدخاله تحت ظلال تلك المصطلحات كالإعلام، الذي وظف في كل بجالات التشويه والتلاعب بالعقول والسيطرة على الأبدان والأفئدة.

ومع أن الدلالات الشرعية واللغوية للمصطلحات واضحة ودقيقة المعالم، وذلك من

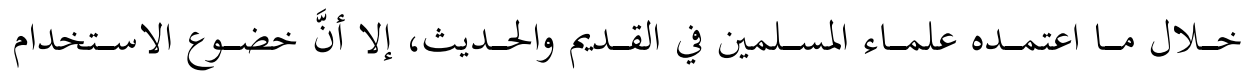
الاصطلاحي لضغوط الواقع المـتردي للمسـمين، وظروف الاستخحام السـلي، أدّى إلى توظيف المصطلحات توظيفاً أضرّ بالمسيرة الإسلامية في بعض الأحيان، مما اقتضى معهد إعـادة النظـر في الاسـتخدام التلقـائي للمصــلحات، ومراجعـة مــا تحملـه الإيحـاءات الاصطلاحية من آثار سلبية على النفسية والعقلية المسلمة.

\section{أولاً: مفهوم المصطلح والاصطلاح}

لا خحلاف في أنّ المصطلح له دور فاعل في تكوين المعرفة بما فيها من حمولة دلاليّة وثقافيّة. ومثل هذه الصورة لما وجهها التبادلي -الجحلي، كون المصطلح لا يخرج عن مقولة

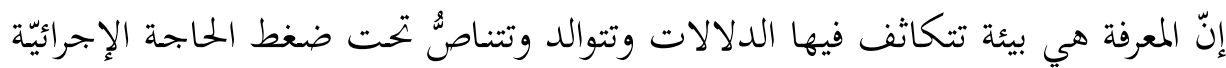
وهذا يساهم في صياغة شكل المصطلح ومفهومه. لذلك فالمصطلح منتجُ ثقافيّ لا يغادر ضوابطها أو معاييرهـا، كونه وجهاً مـن وجوه التواضع التوافقي بين من لهم أهليّة التوليد والصياغة المنتسـبنْن إلى فضـاء دلالي له خصوصسيّته، دفعتهم حاجـة مشتركة إلى توحيــ الخطاب أو تخصيصه ضمن سياق معيّن، تمييزاً له عن الدلالة العفويّة أو المتداول الجمعي. 


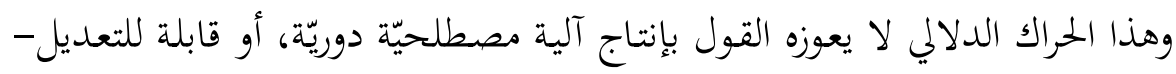

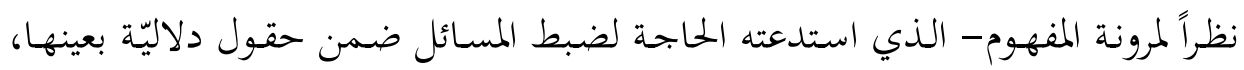

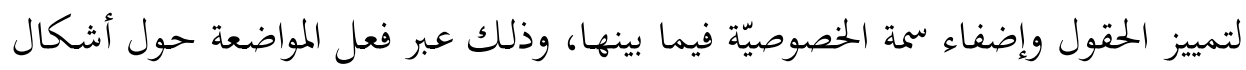

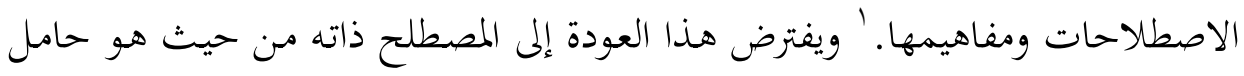

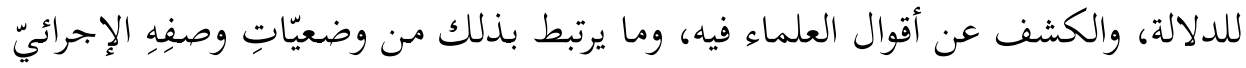

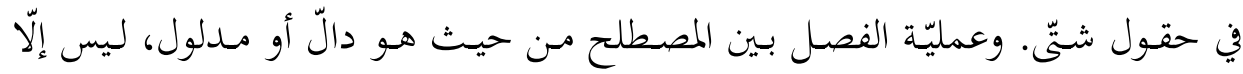

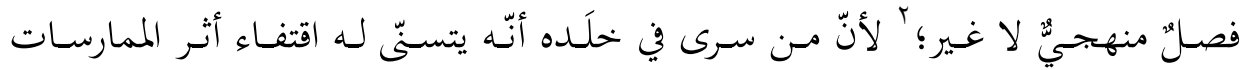

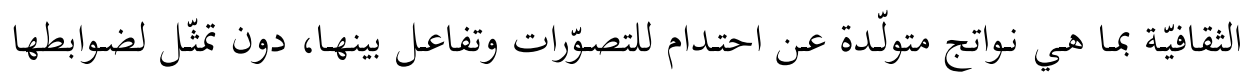

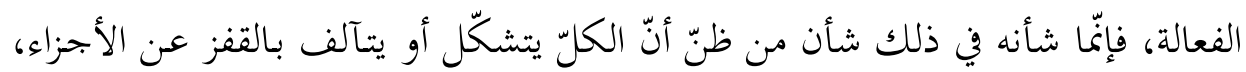

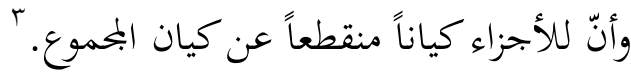

\section{الاصطلاح والمصطلح لغةً واصطلاحاً:}

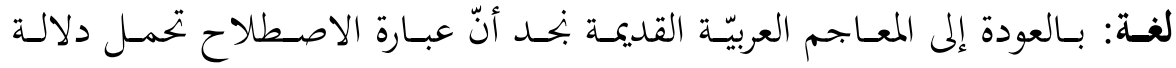

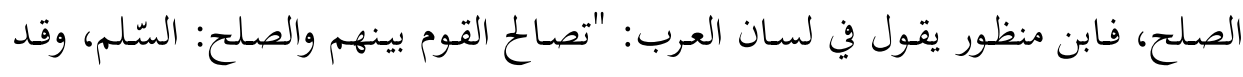

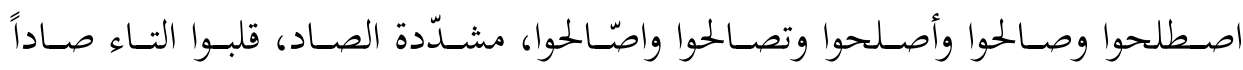

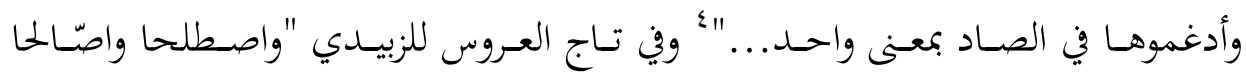

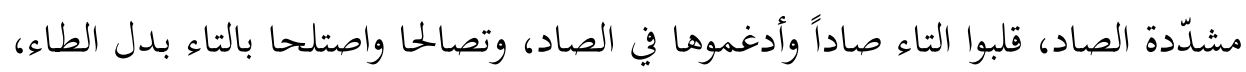

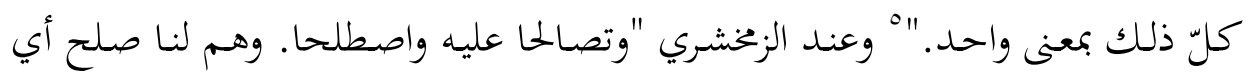

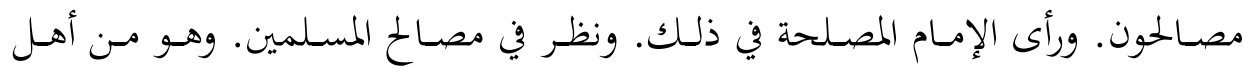

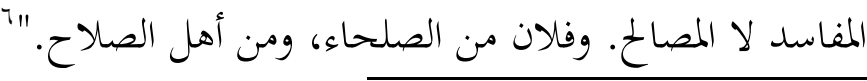

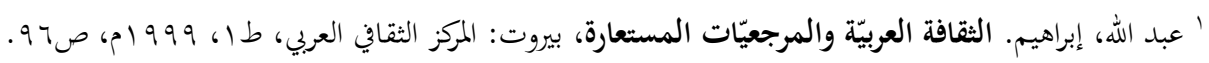

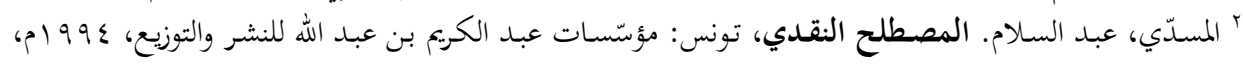

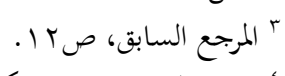

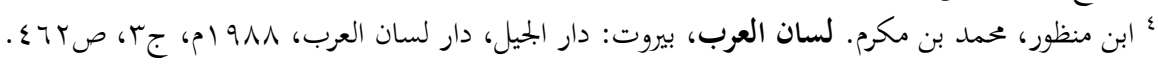

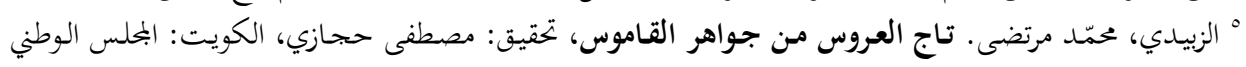

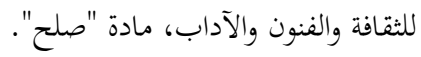
" الزخشري، أبو القاسم محمود بن عمر . أساس البلاغة، تحقيق: محمد باسل عيون السود، بيروت: دار الكتب 
أما اصطلاحاً: فقد قال أبو البقاء الكفوي: "الاصطلاح: إخراج الشيء عن المعنى اللغوي إلى معنى آخر لبيـان المراد.... ويستعمل الاصطلاح غالباً في العلم الذي تحصل

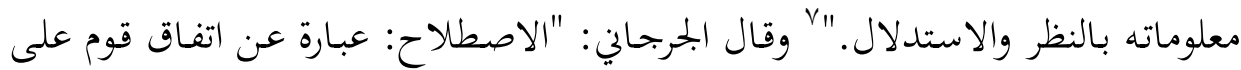
تسمية الشيء باسم ما ينقله عن موضعه الأول.

وواضـح مـا تقدّدم أنّ المعنى المتواضع عليه في المعاجم القديمـة هـو الاتفـاق والتوافق، واصطلح القوم: تصالحوا، بمعنى وقع بينهم صلح، فالتاء بمعنى التشارك والاشتراك، ومعنى التفاعل مخرج من المطاوعة. والاصطلاح في اللغة هو تواضع واتِّاق على معروف، ومعنى الاتّاق مأخوذ من دلالة السّلم، فيكون بذلك معنى الاصطلاح في اللغة هو اتِّاق على معروف وتواضع عليه، وأمّا معنى المعروف فمأخوذ من نقيض الفساد. وأمـا المصطلح فهو: "اللفظظ أو الرمز اللغوي الذذي يستـخدم للدلالـة على مفهوم علمي، أو عملي، أو فني أو أي عمل ذي طبيعة خاصـة." فالمصطلح لفظظ خصصـه الاستعمال في علم مـن العلوم، أو فن مـن الفنون لمفهوم معين، فأخرجهه مـ الاستعمال اللغوي العام إلى استعمال لغوي خاص بعلم من العلوم، فصار له معنى دلالي آخر جديد مغـاير لمعنـاه السـابق، بسبب استعمال ذلك العلم أو الفـن أو الصـناعة لـه في بجالاتـه المختلفة، بحيث إذا ذكرت هذه الكلمة في محيط دائرة ذلك العلم لا يسبق لما معنى إلى الذهن، إلا مـاكـان مـن معناهـا العلمي الخـاص لا اللغوي العـام، وإن كان بينهمـا نـوع ارتباط.

ومهع عـدم تقييـد لفظظ المصطلح في القـواميس العربيّة القديمـة، فقـد شـاع استخدامه

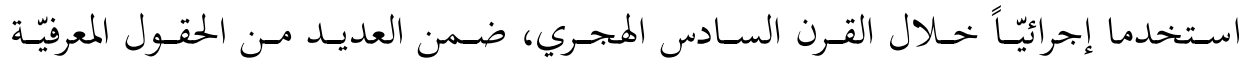
v الكفوي أبو البقاء: الكليّات، تحقيق: عدنان درويش، ومحمّد المصري، بيروت: مؤسّسة الرسالة، طץ، 991 1م، ص9r 11.

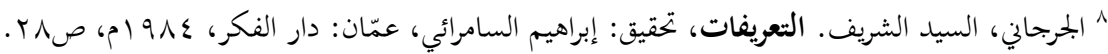

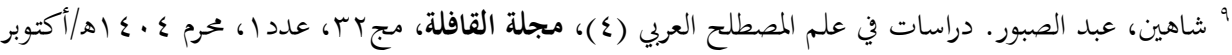


والمحالات المختلفـة، كالتصوّف والتـاريخ، وصـناعة الإنشـاء، وعلوم الحسديث والقـراءات، وصناعة الشعر واللغة والمناظرة، وسميت به بعض المؤلّفات وذكر في ثنايا الكتب. وفي القرن الثاني عشر الهجري، استعمل محمد التهانوي (توفي بعد م1 1 إه) لفظَي

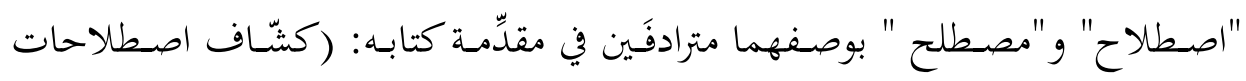
العلوم) حين قال: "فلما فرغتت مـن تحصيل العلوم العربية والشرعية وشثمّرت على اقتناء

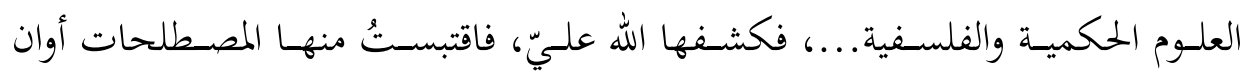

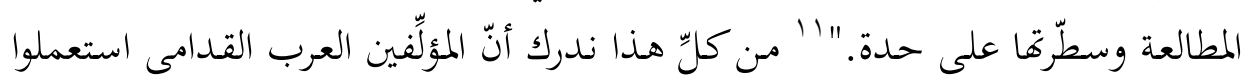

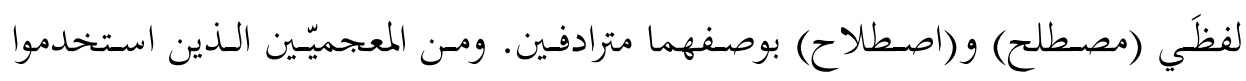

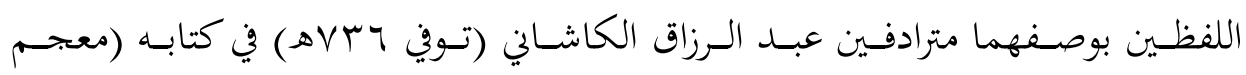
اصطلاحات الصوفية)؛ إذ قال في مقدمته: "...فقسمتُ الرسالة على قسمين: قسم في

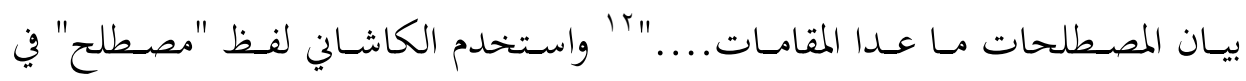
مقدمة معجمه (لطائف الإعلام في إشارات أهل الإلهام) الذي قال في مقدمته: "فإني لما

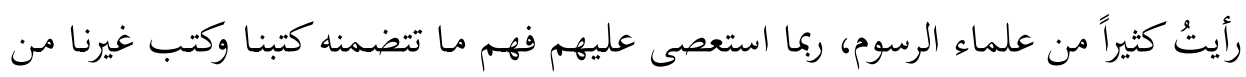

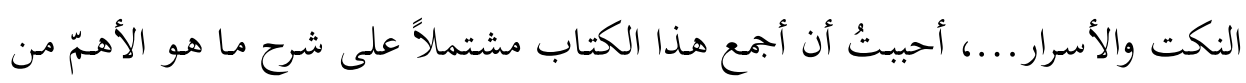

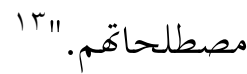

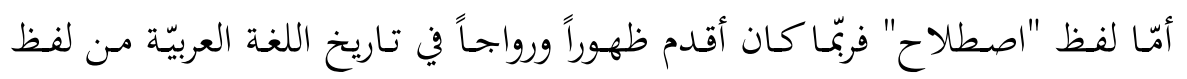
"مصطلح"، فقد استعمل منذ القرن الثالث الهجري في كتاب المقتضب لأبي العبّاس المبرّد

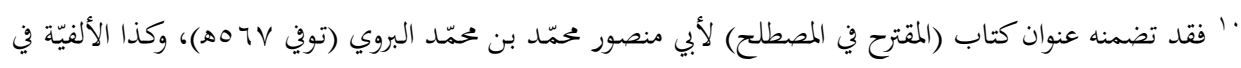

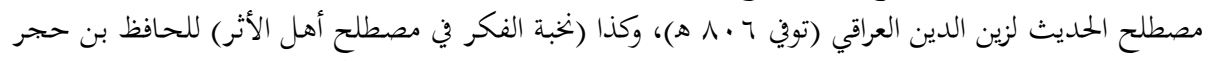

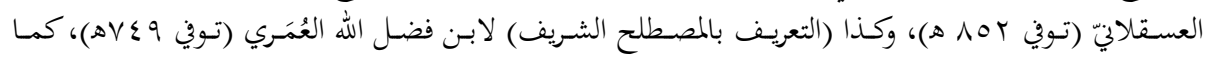

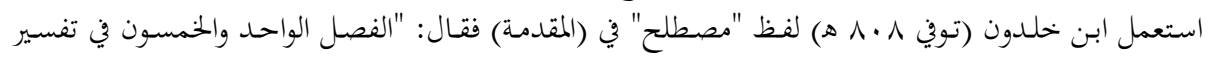
الذوق في مصطلح أهل البيان".

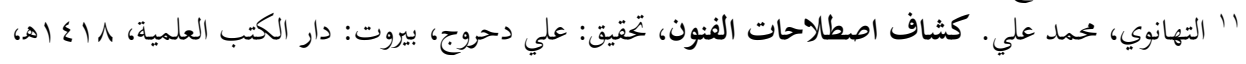
r' الكاشاني، عبد الرزاق. معجم اصطلاحات الصوفية، تحقيق: عبد العال شاهين، القاهرة: دار المنار، و99 ام، r' الكاشاني، عبد الرزاق. لطائف الإعلام في إنارات أهل الإلهام، تحقيق ودراسة: سعيد عبد الفتاح، القاهرة: دار 
علي العاتري ــ الإعلام الإسلامي: إشكالية المصطلح

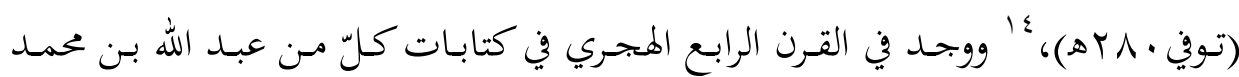

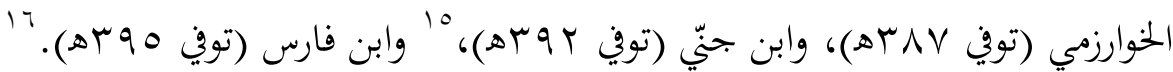

\section{ثانياً: توظيف المصطلح}

الإسلام منهج متميز في كل جوانبه، ومن جوانب التميز دقة ألفاظه، وتحديد معانيها وبنـاء الأحكـام على ذلكـ، فلـيس ثمـة أمـة عنيـت بنصـوص وحيهـا فدرسـت الألفــاظ

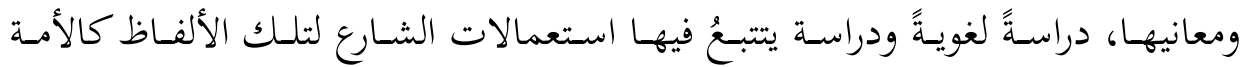
الإسلامية. أما وقد شاع استعمال مصطلح الإعلام في غير معناه اللغوي، فحري بنا تتبع تطورات هذ المصطلح، وأثر استعمالاته في الصراع الحضاري بين الأمم، توصلاً إلى معرفة تاريخه واستعمالاته، وما ذكر عند الناس في معناه، ثم ذكر الألفاظ الشرعية المستعملة في هذا الباب، والمهمات المناطة بالمفكرين وطلاب العلم في تحرير مثل هذه المصطلحات.

إن العلم بحقائق الأشياء، والوعي بالمفاهيم يُعدّ مدخلاً رئيساً لتضييق دائرة الخلاف

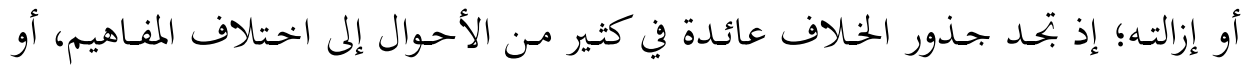

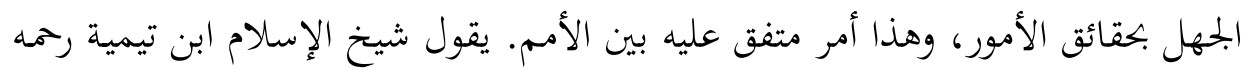

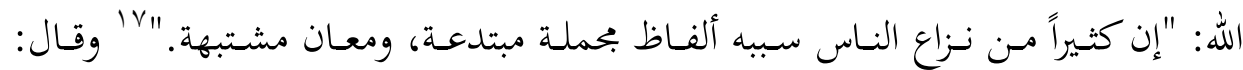

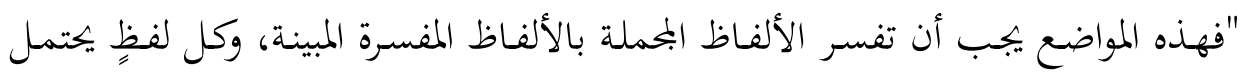

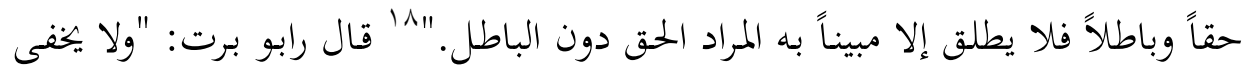

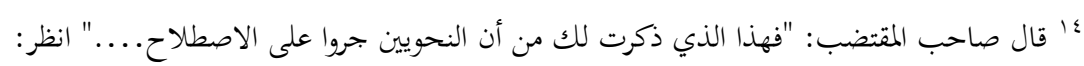

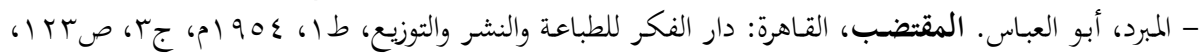
$.11 \leq$

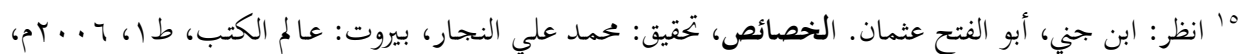

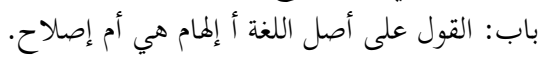

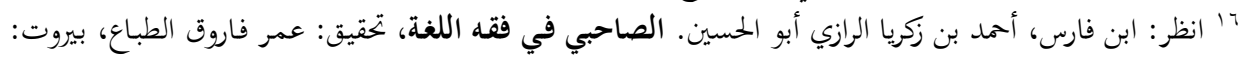

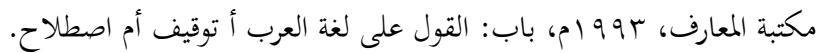

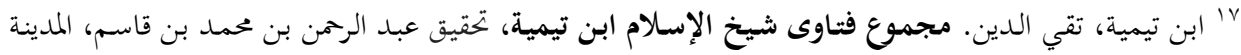

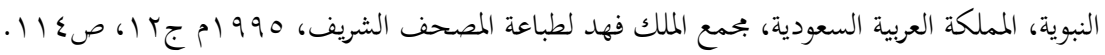

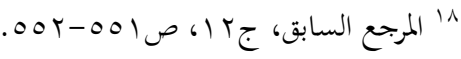




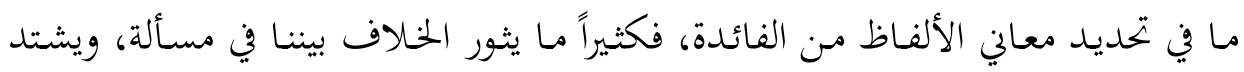

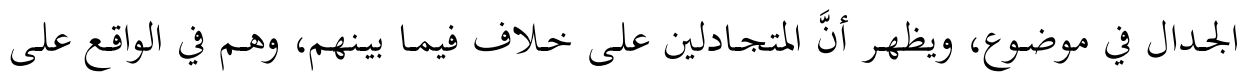

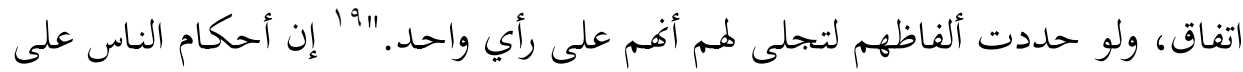

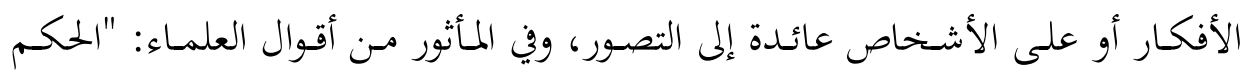

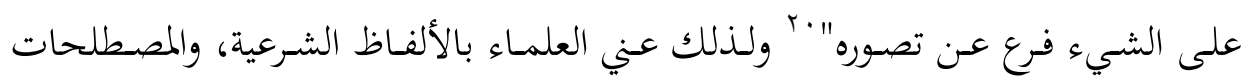

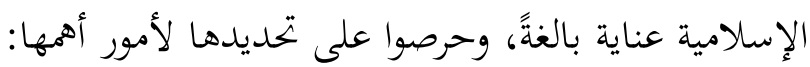

أ. ألّا تكون هذه الألفاظ والمصطلحات نسبية غير محررة يستخدمها كل فريق كما

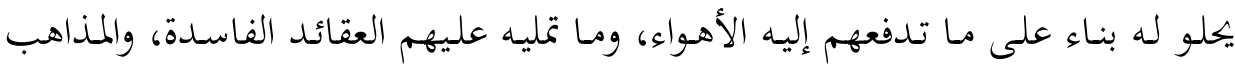

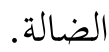

ب. ألاّ تحمل الألفـاظ الشرعية على الاصطلاح الحـادث لقوم أو فئة، فكثير مـن

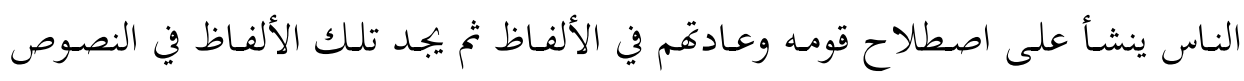

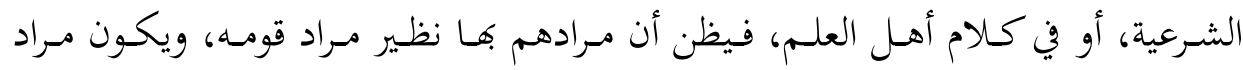

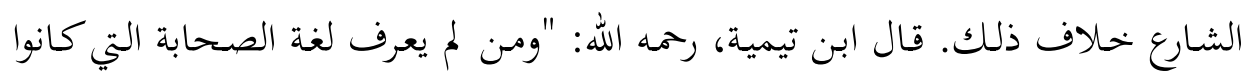

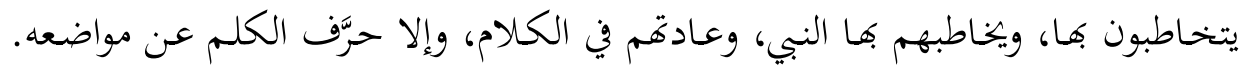

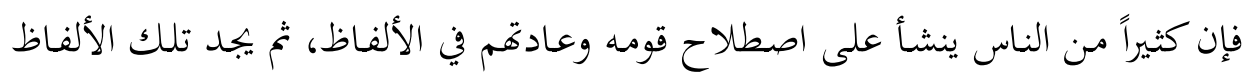

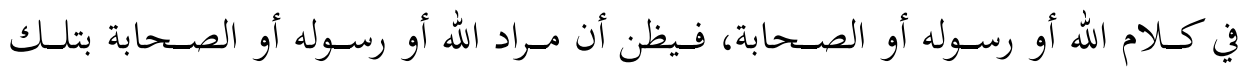

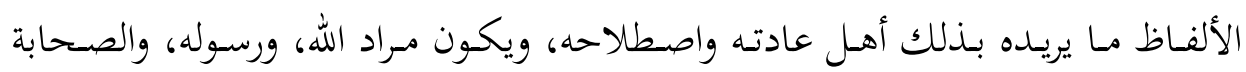

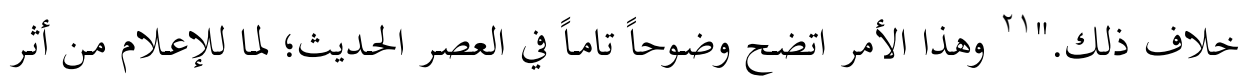
في تغيير المصطلحات بكثرة استعمالها، مراداً بها معاني غير المعاني التي كانت لهان لها أصلاً.

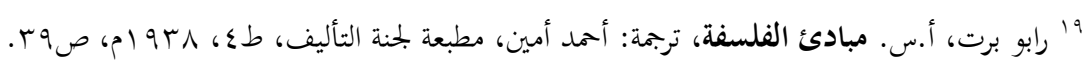

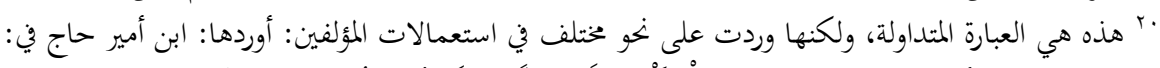

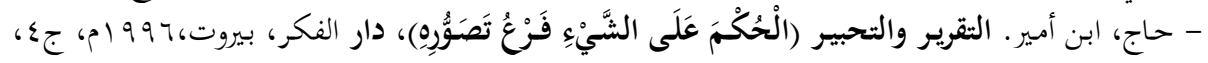

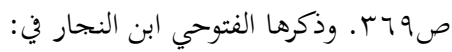

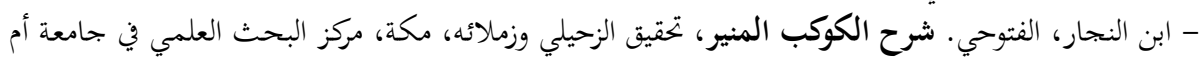

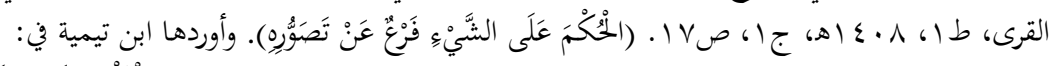

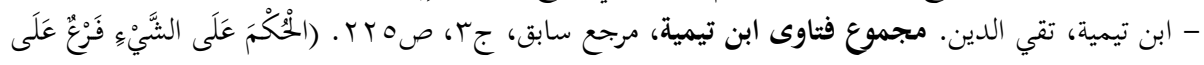


1 ـ استخدام المصطلحات في الصـراع الحضـاري: لقد أصبحت المصطلحات

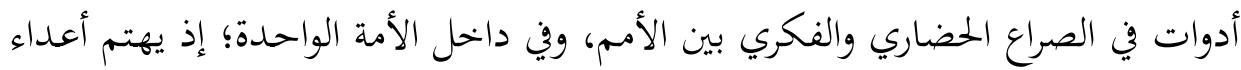

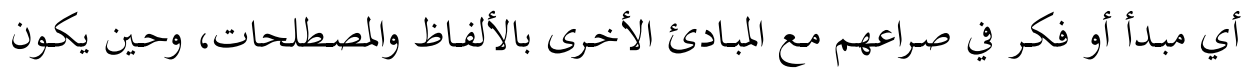

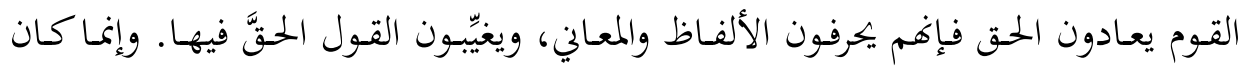

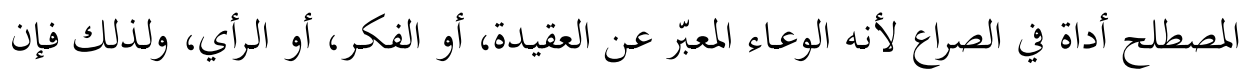

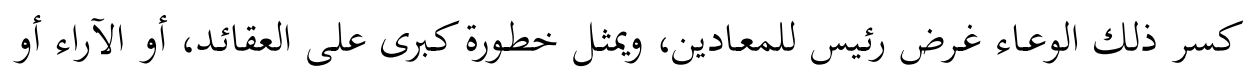

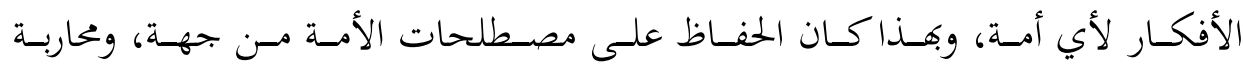
مصطلحات الأمم المعادية من جهة أخرى ركنين أصيلين في عملية الصراع.

إن استخدام أعداء المبادئ للمصطلحات في الصراع الحضاري يقوم على مورين: المحسور الأول: جلب الألفـاظ، والمصطلحات التي هي أعلام على معانٍ سيئة،

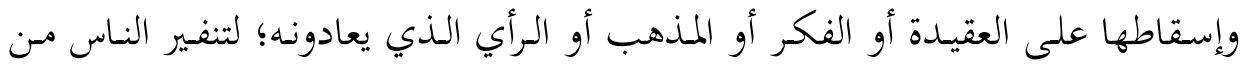

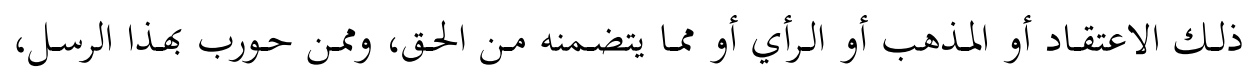

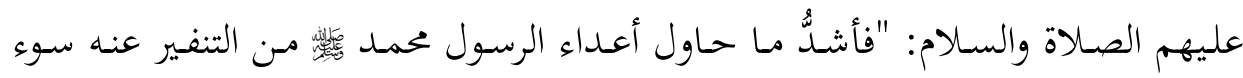

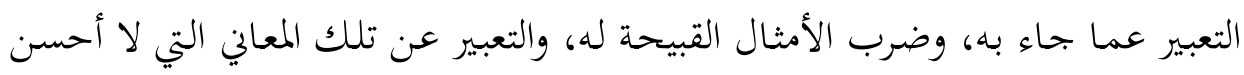
منها بألفاظ منكرة ألقوها في مسامع المغترين المخدوعين فوصلت إلى قلوبهم فنفرت منه،

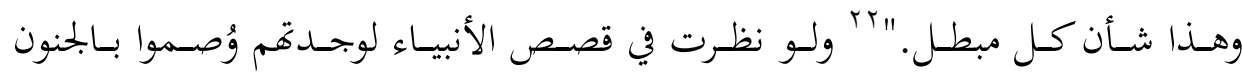
والسفاهة والضلال، وذلك كله لتضليل الناس، وتبغيض هؤلاء الرسل إليهم. وتاريخ الصراع الفكري بين الإسلام والغرب، لا سيما في العصر الحديث يوضح أن

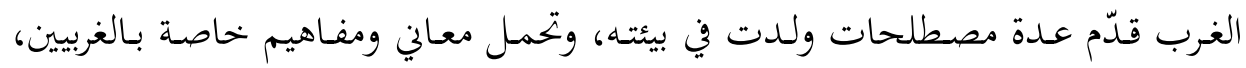

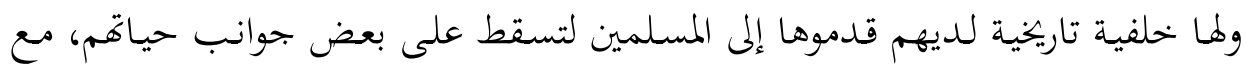

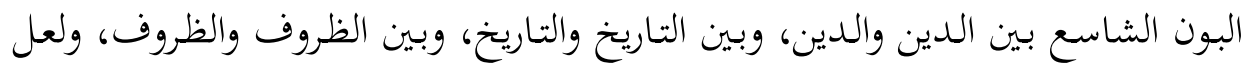
rr ابن القيم الجوزية، محمد بن أبي بكر. الصـواعق المرسلة على الجهمية والمعطلة، الرياض: دار العاصمة، 
مـن الأمثلـة الواضـحة على ذلـك المصـطلحات الآتيـة: الإعـلام، الدعايـة، الإرهـاب،

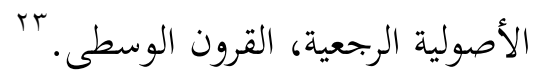

فكل هذه المصطلحات ترمز إلى مذهب أو حالة معينة، وركن يأبى الغربيون إلا أن

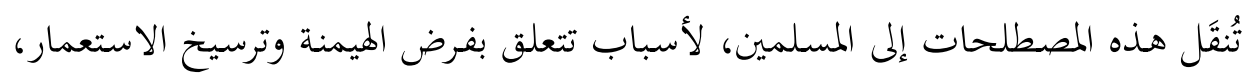

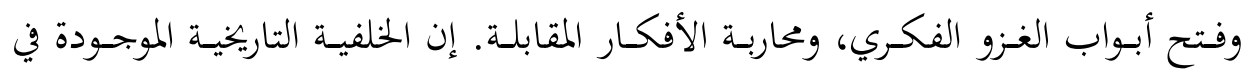

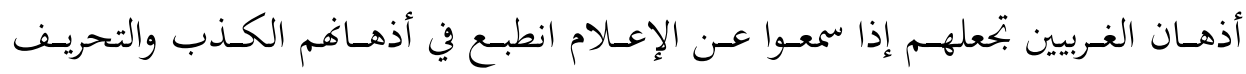
والتشـويه. فاختيـار هـذا المصطلح واستعماله في غـير معنـاه الأصسلي ينفِّر المسـمين مـن

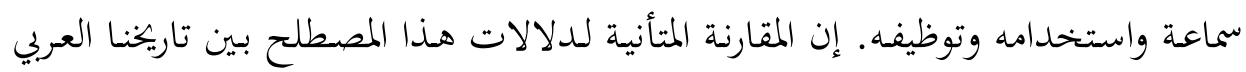

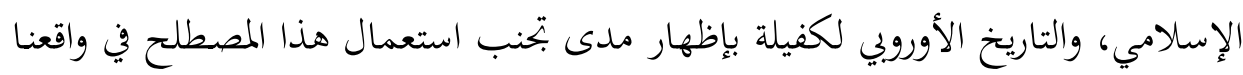

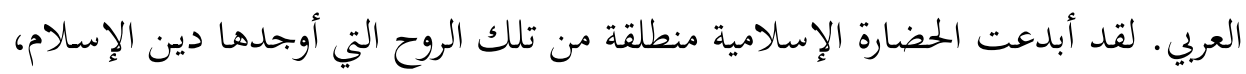
في حين ولدت الحضارة الأوروبية الحديثة في واقع صراعها ضد جمود رجالات المسيحية، تم إن عصور الظلام الأوروبي التي أطلق عليها وصف (القرون الوسطى) هي زمنياً العصور

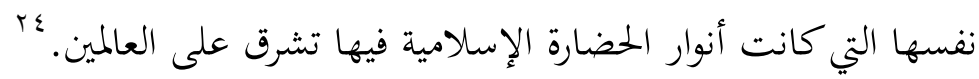

المحور الثاني: أخذذ الألفاظ السليمة والصالحة، وجعلها أعلاماً على ما ينفر منه

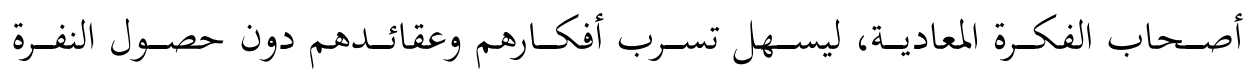
والكراهـة. ومسن أمثلـة ذلك في الصـراع الفكري في الحيـاة المعاصـرة المصطلحات وعات الآتيـة: (العلمانية، الإصلاح، التقدمية، العقلانية، الإعلام، الدعاية).

واستخدم مصطلح الإعـام في الحضـارة الإسـلامية لتبليغ رسالة الإسـام إلى النـاس كافة، في حين ولد المصطلح في الحضارة الأوروبية الحديثة في واقع حربها ضد الإسـام.

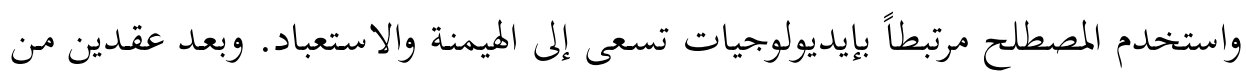

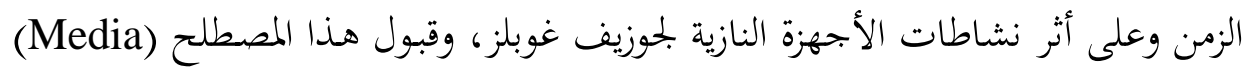

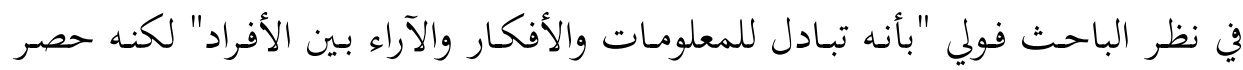

rrr

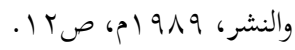

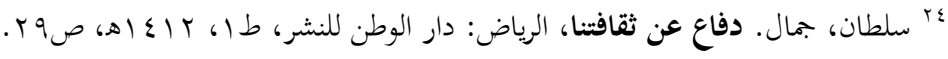


مفهوم الإعلام في عملية تبادل المعلومات وأهمل الوسيلة. ويرى الباحث فرانسيس بال بأن

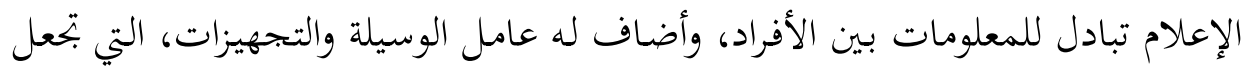

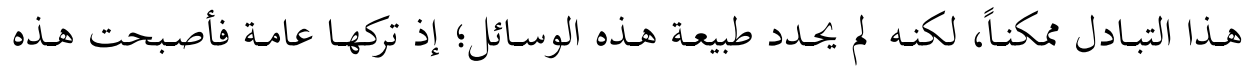

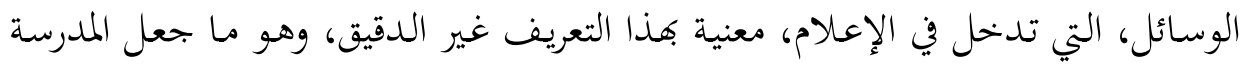

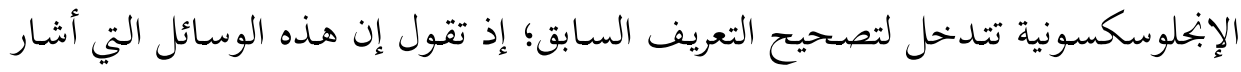

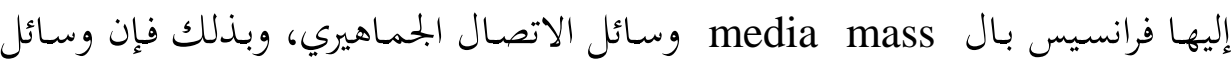
الإعلام هي وسائل الاتصال على النطاق الجماهيري.

ومع هذه التعريفات وغيرها يبقى المفهوم غامضاً غير دقيق، مما أدى إلى استخدامه

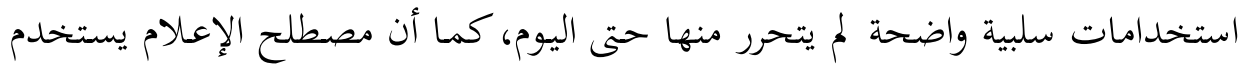

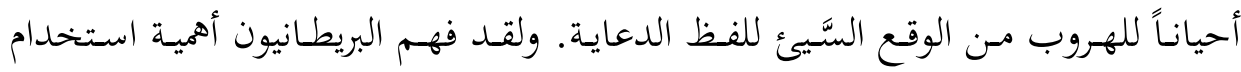

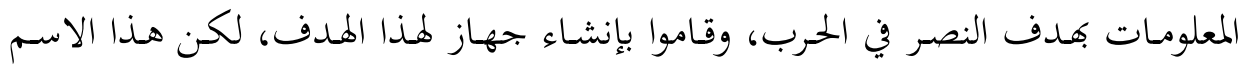

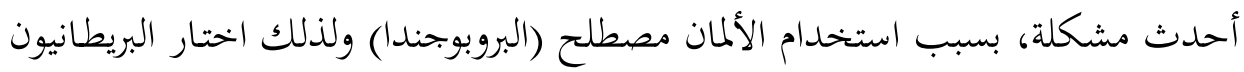

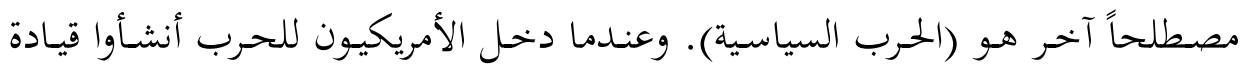

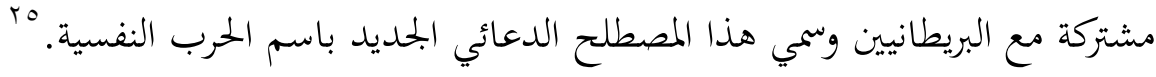

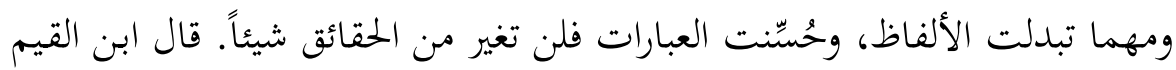

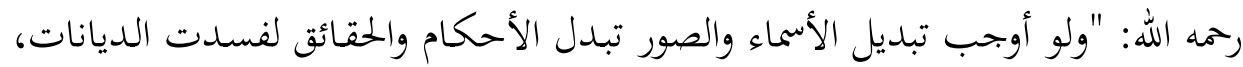

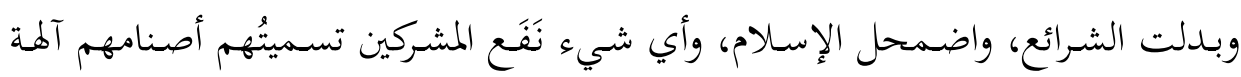

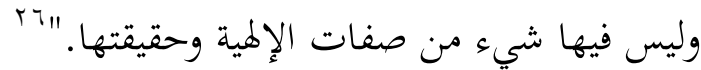

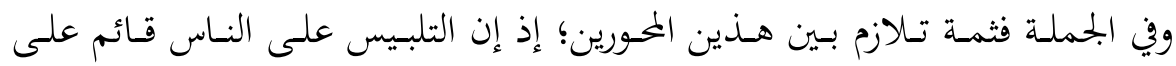

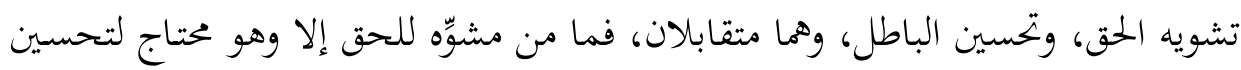

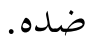

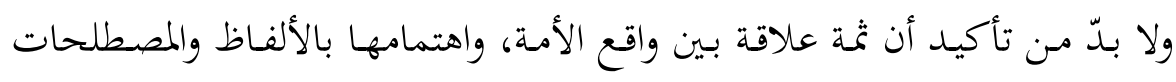

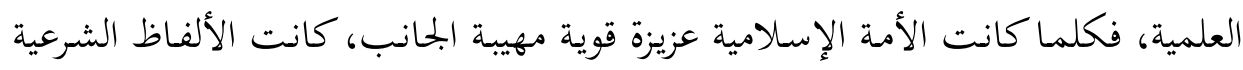

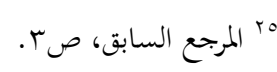

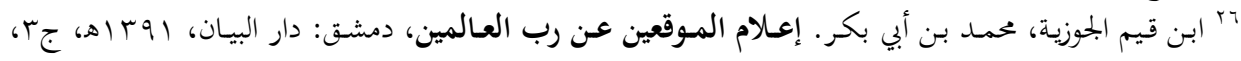




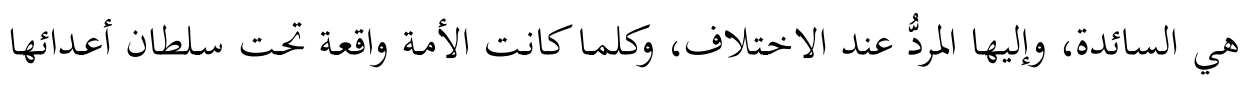

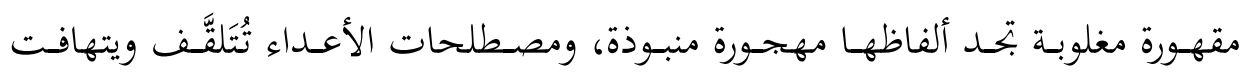

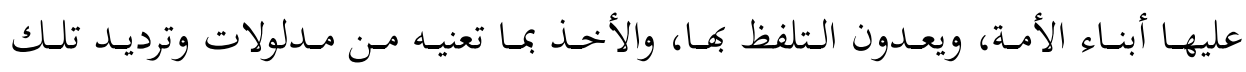

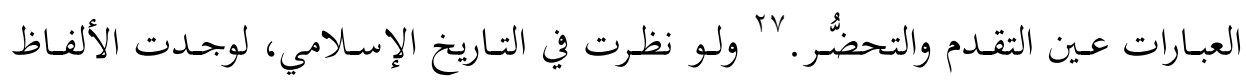

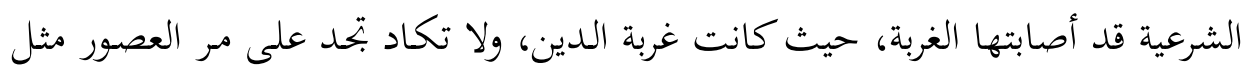

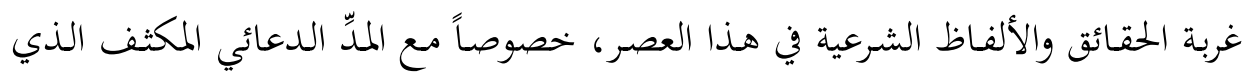

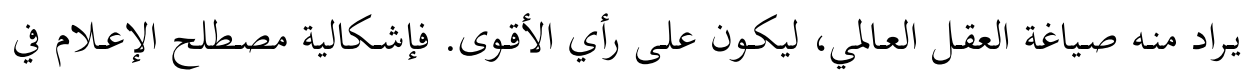

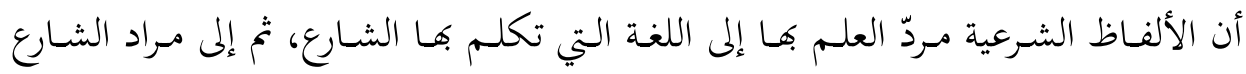

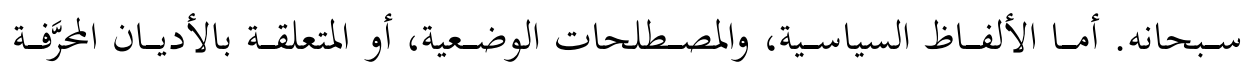
والحضارات فإن دراستها خختلفة؛ فكل مصطلح له أصول يدرس بها.

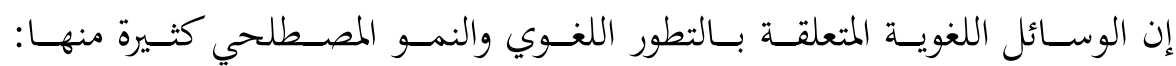

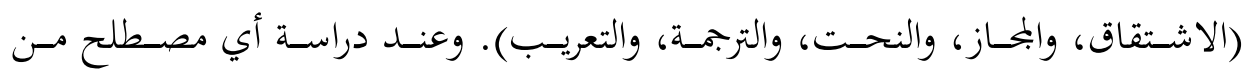

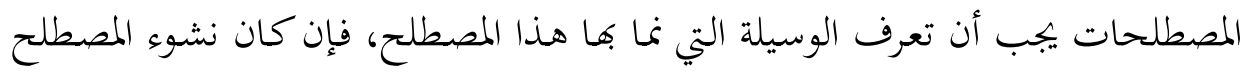

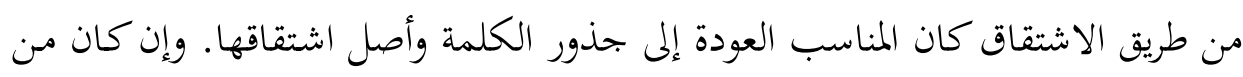

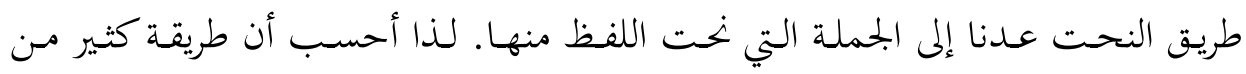

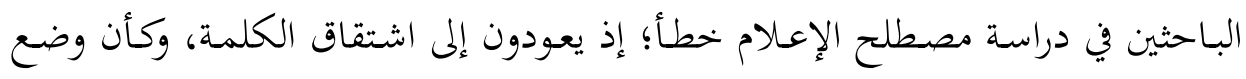

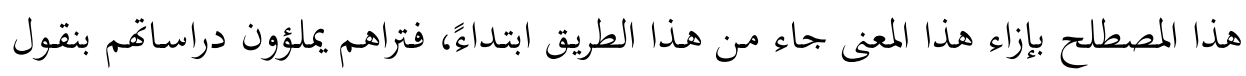

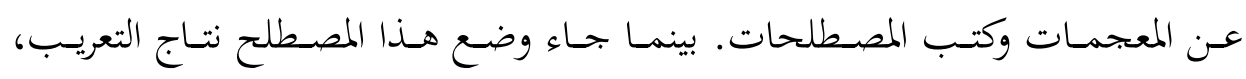

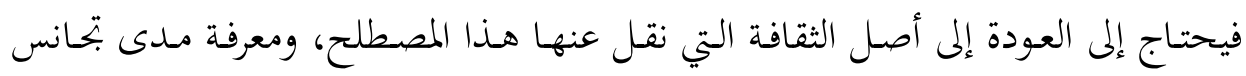

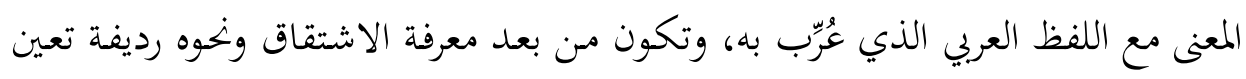

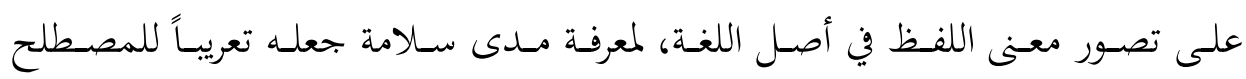

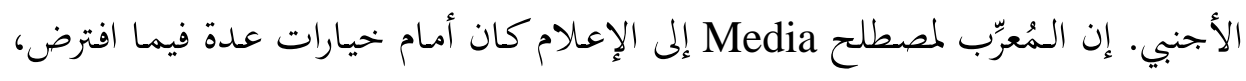

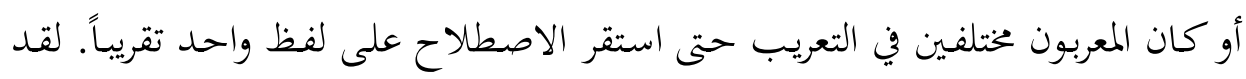


كانوا أمام ألفاظ كالدعوة والنشر والتبليغ والإعلام، وقد آثروا استخدام لفظ الإعلام، ثم أضاف إليه دعاة الأسلمة والتأصيل لفظ الإسلامي، فاصطلحوا على تسمية هـذا الفن

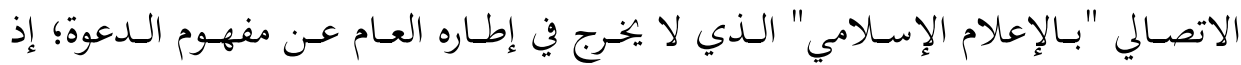

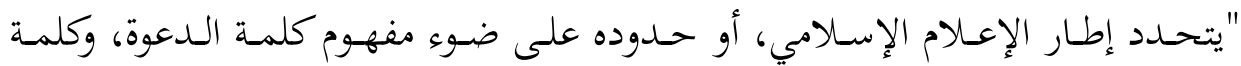
الدعوة من الألفاظ المشتركة التي تطلق اسماً ويراد بها الدين، أي حقائق الإسلام، وأركانه، وتكاليفه..." "rالوالدعوة بهذا المعنى مرادفة لكلمة الاتصال الذي يعني كما يرى هوفلاند:

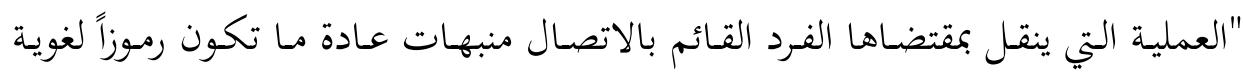

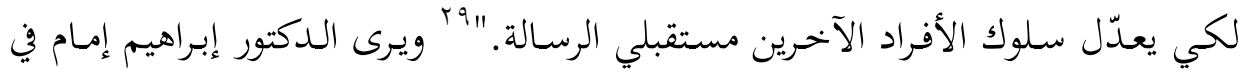

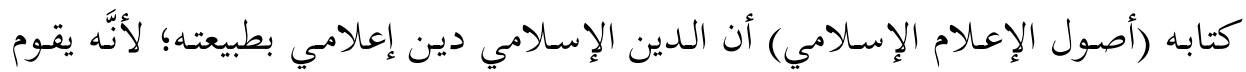

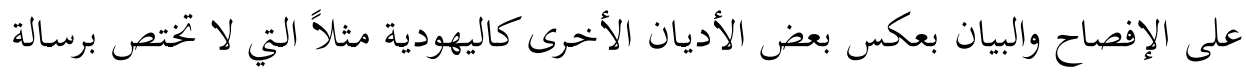

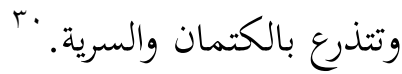

وأعتقد أن هـذا الاختيـار لمج يبنَ على أصسول علميـة، بـل مبنـاه على أمرين أو على أحدهما: أغراض وأهداف المترجمين ومن وراءهم، والإعلام العالمي الموجَّه. إن بين استخدام المعاصرين لمادة (اعلم) وما اشتق منها، واستعمالات هـذه المـادة

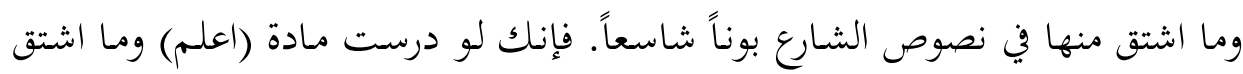
منها في ألفـاظ الكتاب والسـة لوجدات المعاني السامية والمحمودة، أمـا المعاني السيئة مـن الكذب والتزييف والتحريف والخداع فتدل عليها ألفـاظ شرعية دقيقة تبنى عليها أحكام في غاية الانضباط.

وعند استعراضنا لنماذج من تعريفات الإعلام الإسالامي منها: هو "تزويد الجماهير

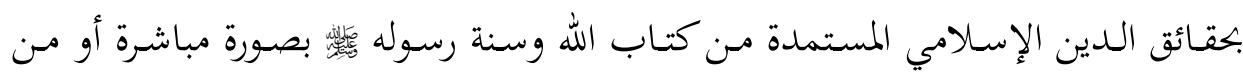
خـالال وسـيلة إعلاميـة عامـة، بوسـاطة قـائم بالاتصـال لديـه خلفيـة واسـعة متعمقـة في ^^ا البدوي، حسن عبد الرؤوف. "سلوك الداعية وأثره في تبليغ الدعوة الإسلامية"، (رسالة ماجستير، جامعة الأزهر،

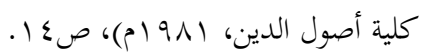

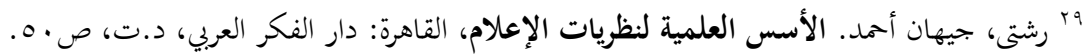

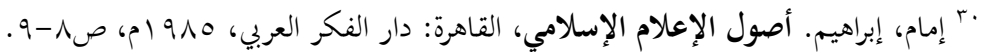


موضوع الرسالة التي يتناولها، وذلك بغية تكوين رأى عام صائب يعنى بالحقائق الدينية

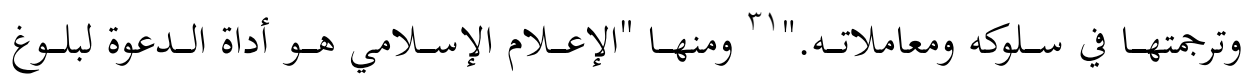

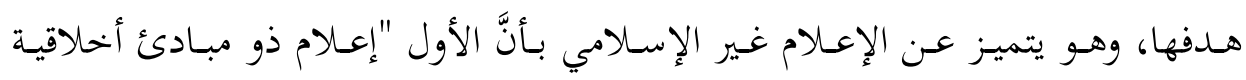

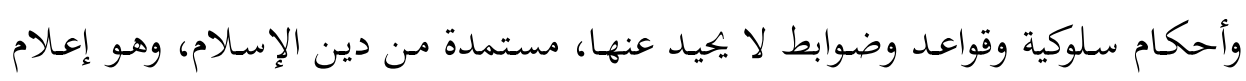

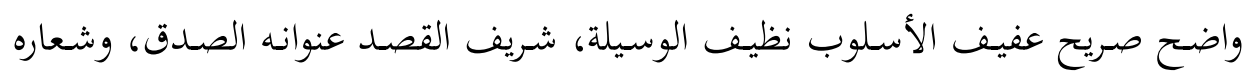

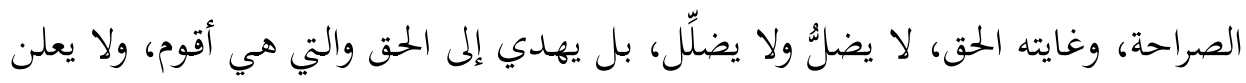

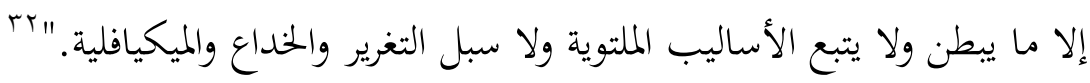
ومنها أنه "لفظظ جديد يعبر عنه القرآن الكريم بلفظ آخحر بديل هو الدعوة التي

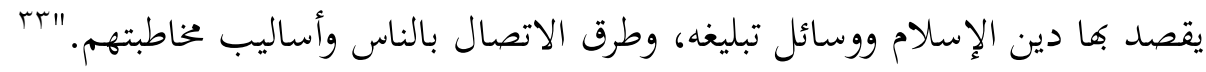
ونستنتج مما سبق الأمور الآتية:

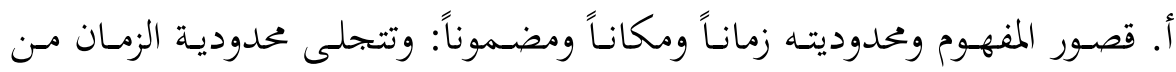

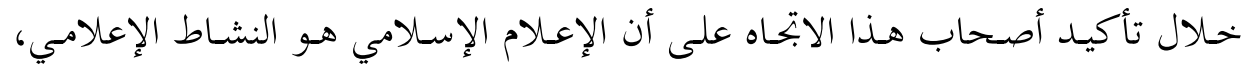

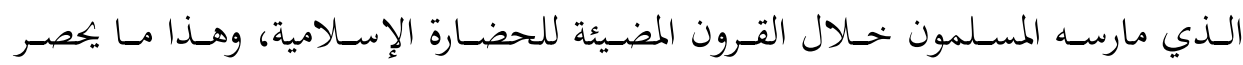

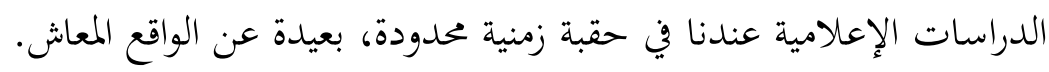

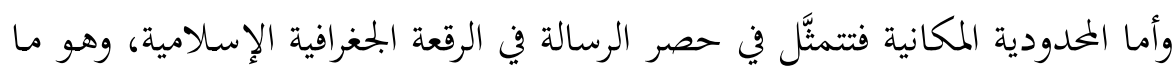

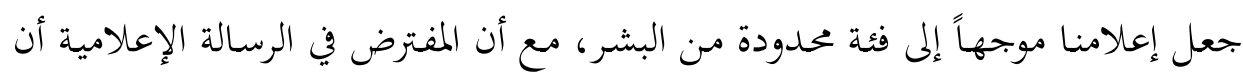
تكون موجهة لكل الناس، بغض النظر عن الجنس أو اللون أو العِرق أو الدين.

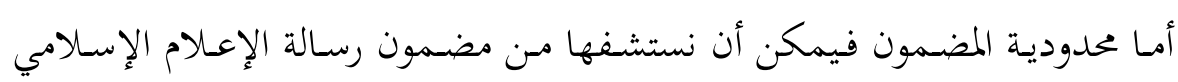

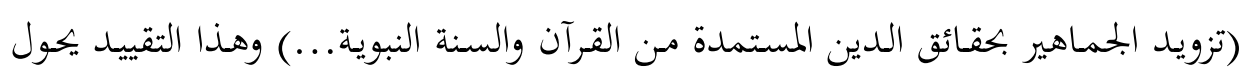

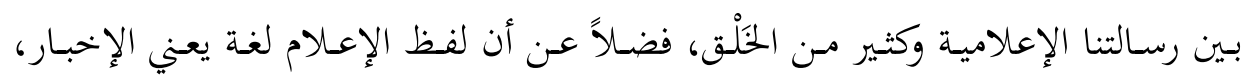

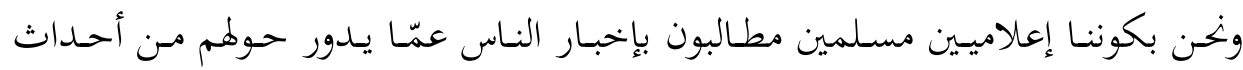
بصدق وبترد، سواء كانت إيجابية أم سلبية.

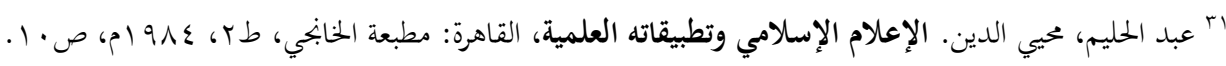

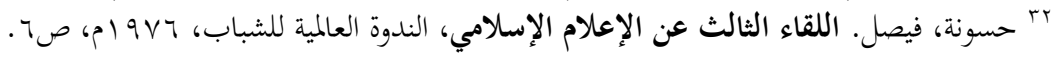

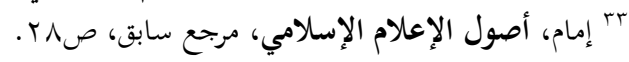


إن الاختلاف بيننا وبين الغرب ليس في مصطلح (الإعلام) فحسب، بل الاختلاف في أصل الدين، وما المواقف من الحياة والأحياء والأشياء إلا نتاج ذلك، ولا يمكن للخلق

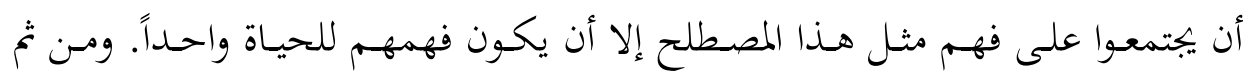

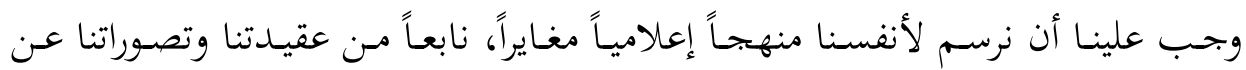

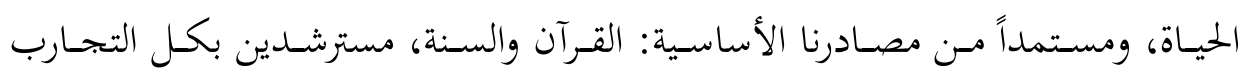
التاريخية لأمتنا، غير مستنكفين عن الأخذ بكل ما توصل إليه غيرنا من تقنيات. ب. التعريفات نسبية وحمّالة وجوه: إن الشأن في المصطلحات وتعريفاقا أن تكون منضبطة ومحررة، بحيـث لا يحملهـا كل أحسد على مـا يـراه، والقـارئ لتعريفـات (الإعـلام الإسالامي) يظهر له أن المصطلح حمّال وجوه لا يمكن ضبطه. ت. افتقـاد المعيـار: لا بـد عنــ التنـازع في قضسية مـ القضـايا مـن مرجع يرجع إليـه

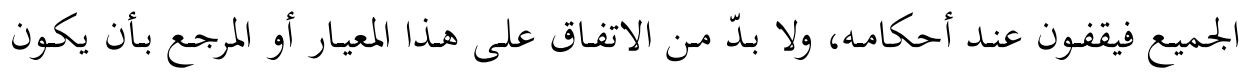

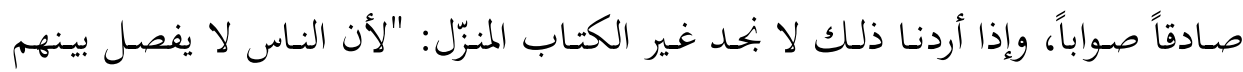

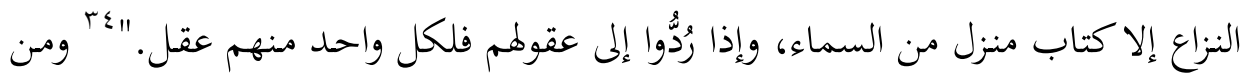

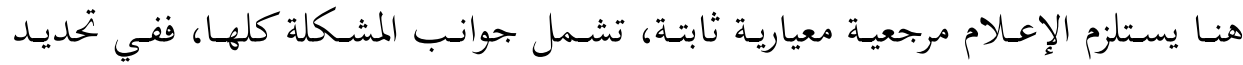
حقيقة الإعلام وماهيته لا بدّ من مرجع. وفي الحكم على عمل من الأعمال أو قول بأنه

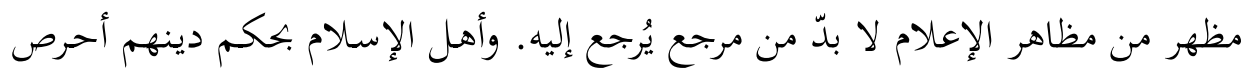

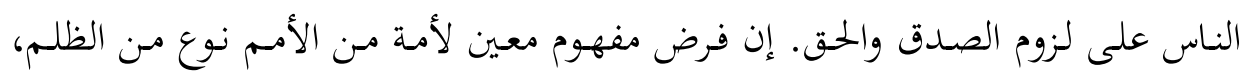
فكيف إذا انضـاف إلى ذلك أن المفهوم عنـدهم لم يتحـرو؟! وكيـف إذا كانـت الظواهر تدل على أن المفهوم مفهوم متسمٌ بسمات بتعله غير مقبول؟! ث. عـدم وفـاء اللفظظ للمعـاني الداخلة فيـه: إن الأنشطة المعينـة التي يـراد تسميتها

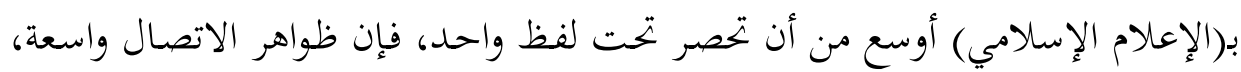

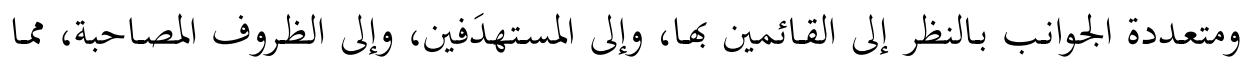
يجعل جمعها تحت لفظ واحد تعميماً وتعويماً يخالف التحديد المنضبط للمعاني، الذي هو

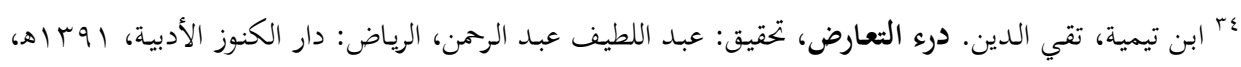


سمة من سمات الأحكام. إن هذه المآخذ هي على التعريف والمفهوم القائم، بل إن بعض

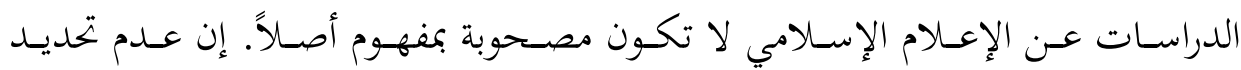

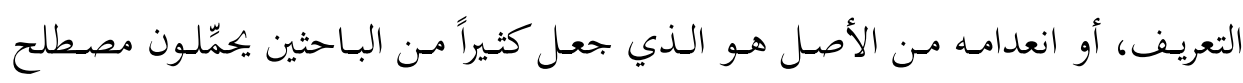
الإعلام الإسلامي مـا لا يطيق، ويُدِخِلون ضمنه كل تضليل وتحريف وتشويه للحقائق،

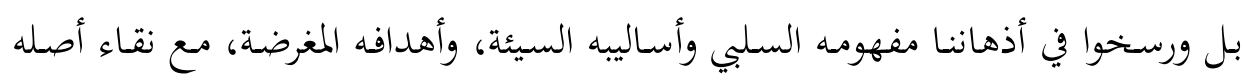
ومتانة جذوره، وهناك من جعل الإعلام الإسلامي هو الإسلام نفسه.

ج. الخلـط بـين الإسـام والإعـلام الإسـلامي: إن النسـبة الإســادية بتعلنـا نحكـم

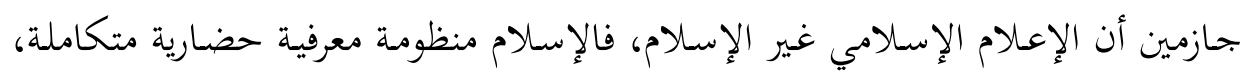
والإعلام وسيلة لإيصال تلك المنظومة المعرفية إلى الآخرين.

وتكمن الخطورة في هذه النسبة عندما تتبنى المؤسسة الدينية ذلك الإعلام، لتظهر الإسـلام بشـكل خـاص، مــا يـوهم المتلقـي بــلك الارتبـاط الـوهمي بـين جـزأي النسبـة

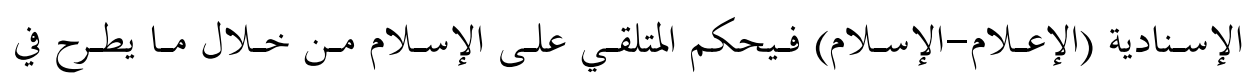

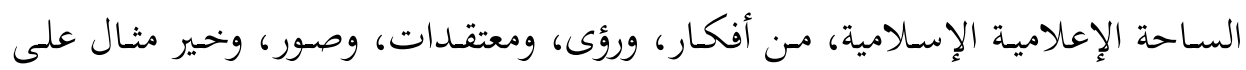

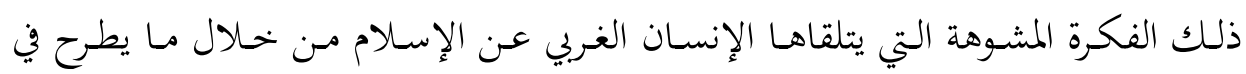

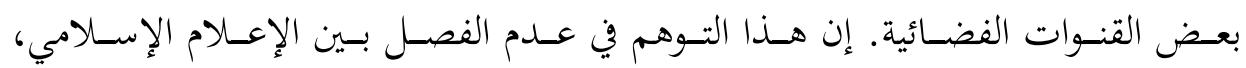
والإسلام، منح الأعداء فرصة إبراز الإسلام في صورة مشوهة بالتركيز على المظاهر السلبية التي يعاني منها المسلمون، وتبرزها وسائل إعلامهم التي تمثل الإسلام في نظر الغرب. Y. لا مشاحّة في الاصطلاح: وقد يعترض معترض على ما ذهبنا إليه آنفاً بقوله:

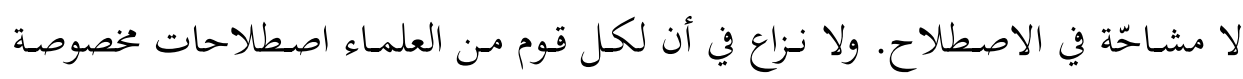
يستعملوغا في معان مخصوصة؛ إما لأفم نقلوها بحسب عرفهم إلى تلك المعاني، أو لأه内م

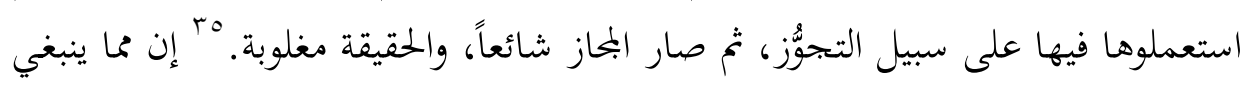

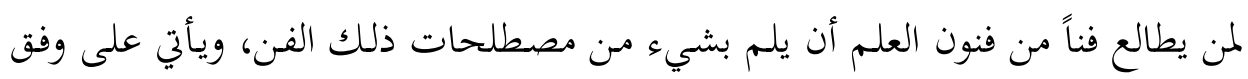
ما اصطلحوا عليه، وذهبوا إليه.

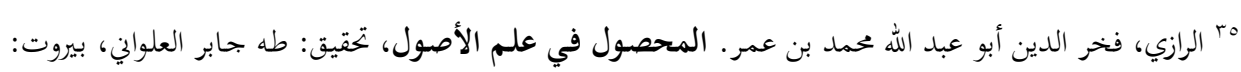

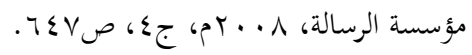




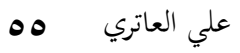
الإعلام الإسلامي: إشكالية المصطلح

يقول ابن قيم الجوزية: "لا ننكر أن يحدث في كل زمان أوضاع لما يحدث من المعاني التي لم تكن قبل، ولا سيما أرباب كل صناعة فإهم يضعون لآلات صناعاهم من الأسماء

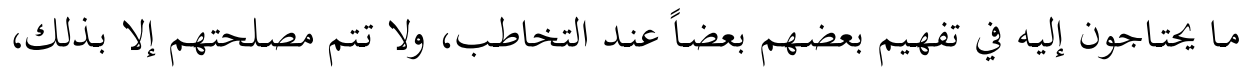

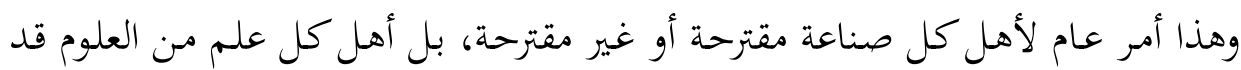

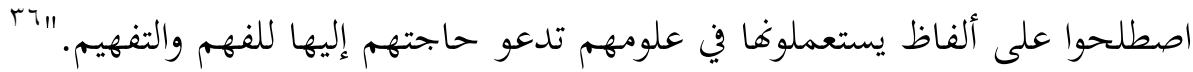
وقد اعتنى أصحاب كل فن بإبراز مـادهم مـن كل مصطلح درجـوا عليه، وإظهار قصدهم من جميع العبارات التي تتوارد على ألسنتهم في مخاطباتم ومصنفاهم. وبعضهم خصصوا كتباً لإبراز فحوى المطالب الاصطلاحية، وشرحها بأوجز عبارة؛ تسهيلاً لمن أراد ارتيادهـا. وإنمـا وضـت (مصطلحات الفنـون) لتقريـب معـاني كل فـن، وضـبط قواعـده ومباحثـه، وهـذا "مـن أصـدق دلالة علي عظيم الجهـود المبذولة في خدمـة العلم وتـذليل صعابه، وتقريب بعيده، وجمع متفرقه من أهل العلم في كل عصر ومصر. بV" وعبارة لا مشـاحِّة في الاصطلاحح ^ب يقولوها في كل مرة وجـد التوافق في المعني، مـع الاختلاف في اللفظظ والمبنى، ويعنون بـذلك: أنه لا منازعـة ولا ظنـة على اللفظـ مـا دام بm الدمياطي، البكري بن محمد. إعانة الطالبين على حل ألفاظ فتح المعين، بيروت: دار الفكر، 9191 (م) جr،

$$
\begin{aligned}
& \text { صهr. }
\end{aligned}
$$

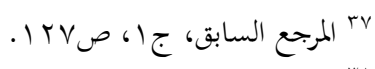

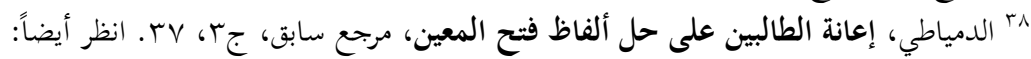

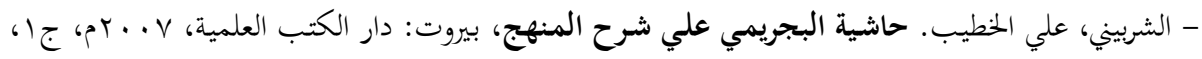

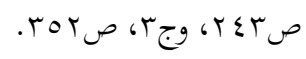

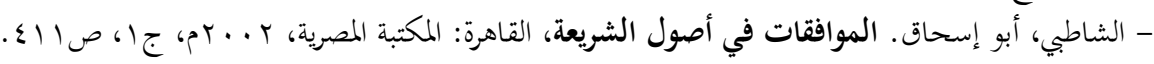

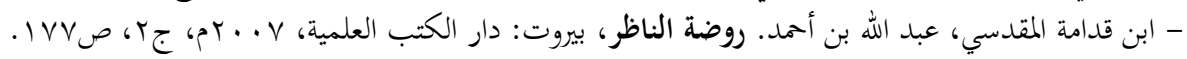

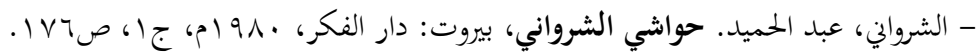

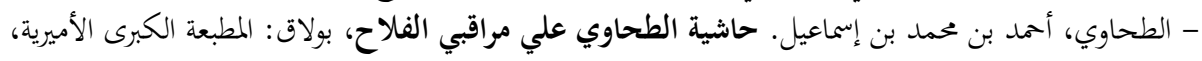

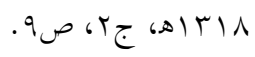

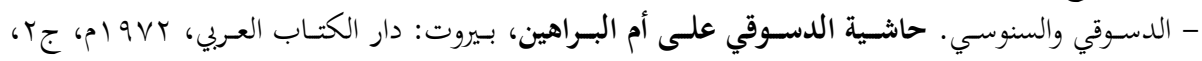
صזr.

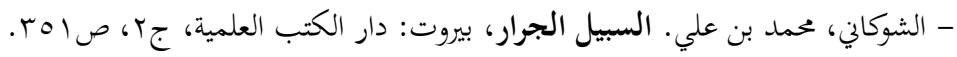

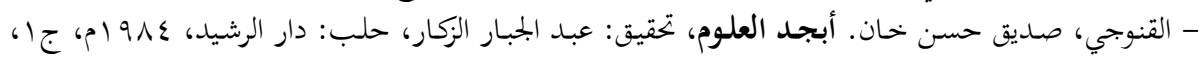




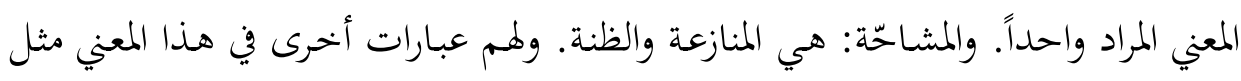

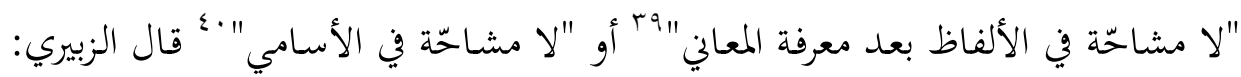

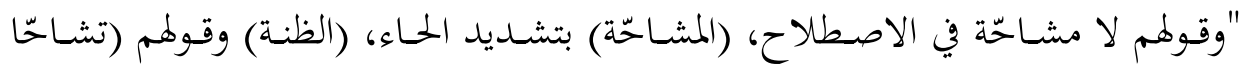

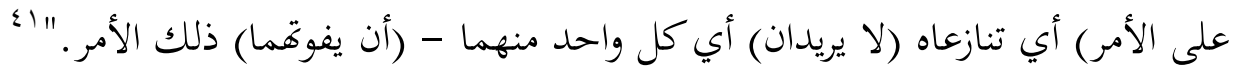

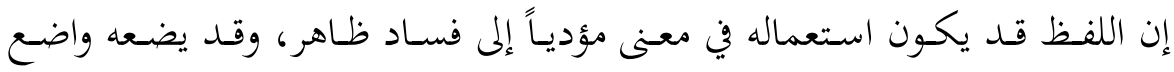

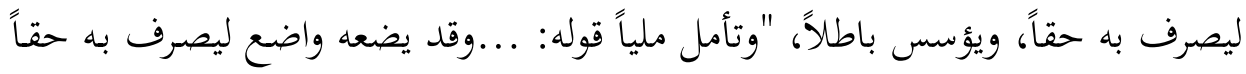

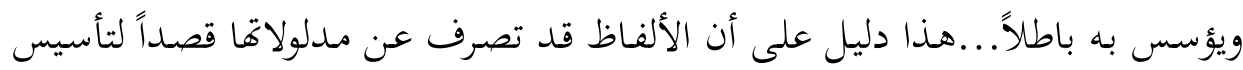

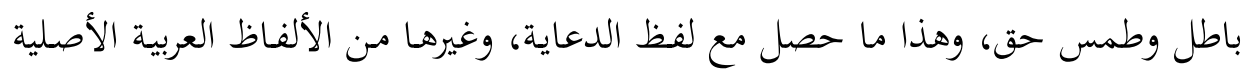

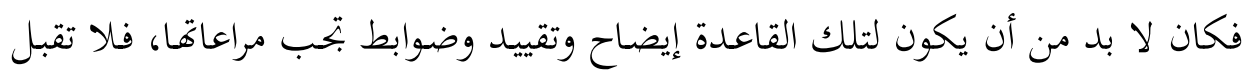

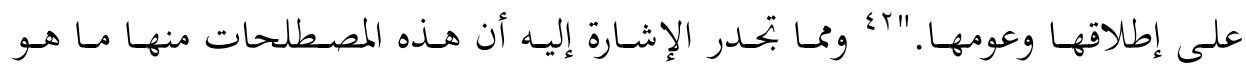

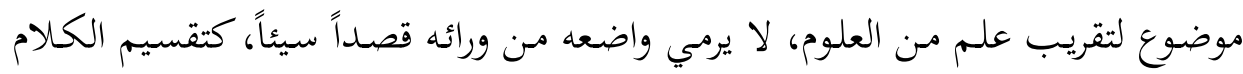

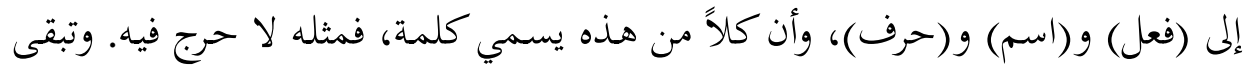

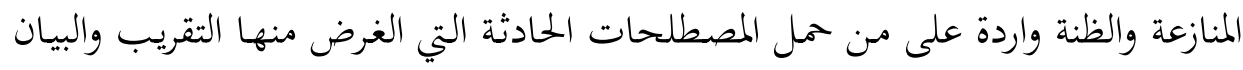

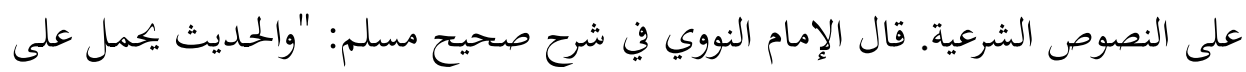

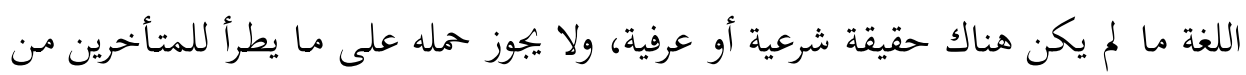

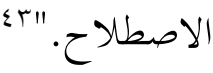

وقال الحافظ ابن حجر: اللفظ لا يحمل على الاصطلاح الحسادث. ؛ وهلـذا فلا

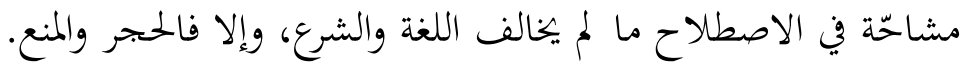

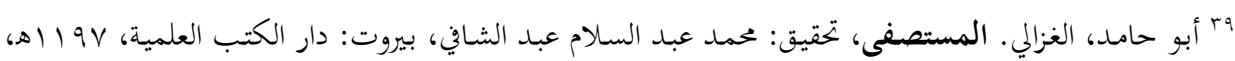

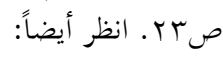

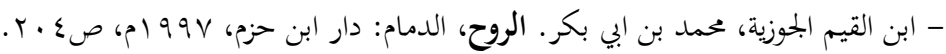

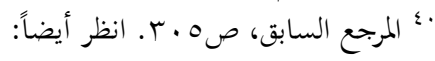

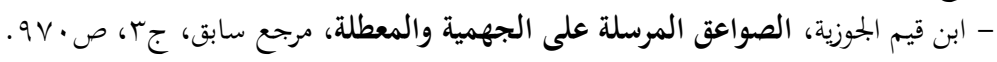

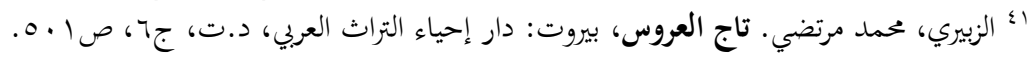

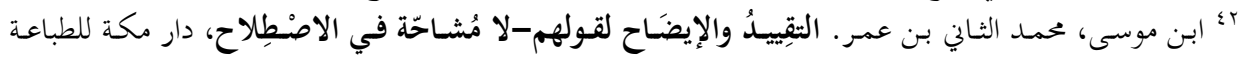

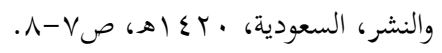

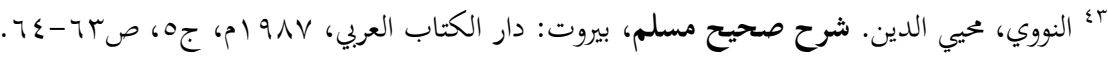

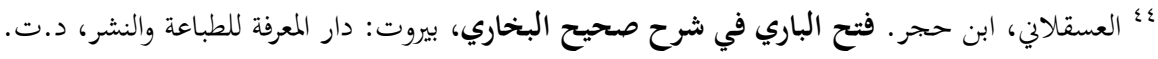


قال ابن القيم: "ولا حجر في الاصطلاح ما لم يتضمن حمل كلام الله ورسوله عليه

الصلاة والسلام فيقع بذلك الغلط في فهم النصوص ومملها على غير مراد المتكلم منها."

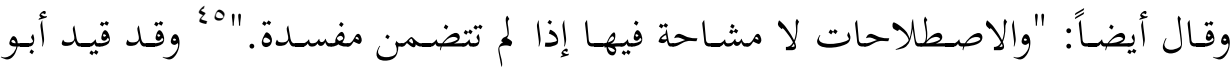

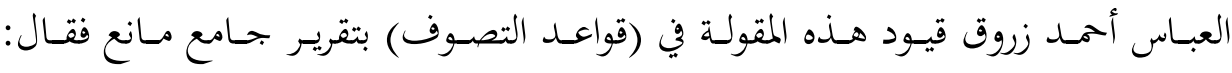
"الاصطلاح للشيء، مما يدل على معناه ويشعر بحقيقته ويناسب موضوعه، ويعين مدلوله

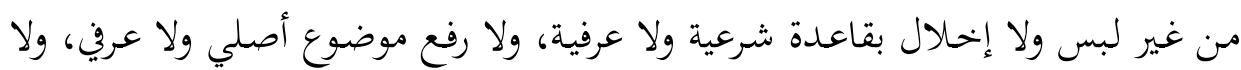

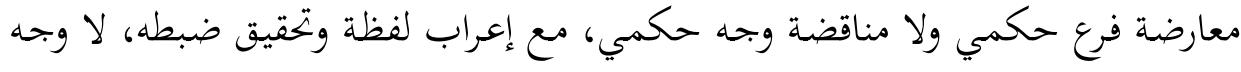

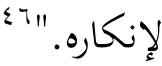

ونستطيع أن نكيّف حقيقة الاصطلاح في ضوء ما ذكر أنه: "اللفظ المختار للدلالة

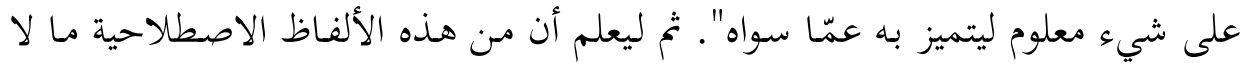

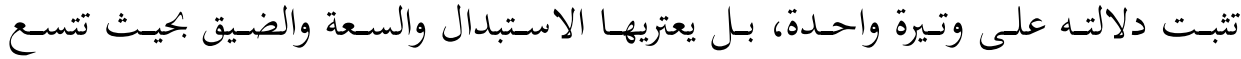

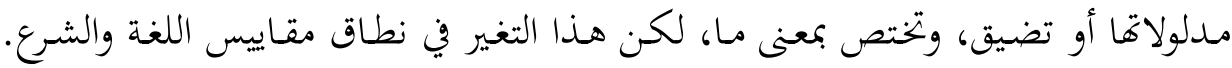

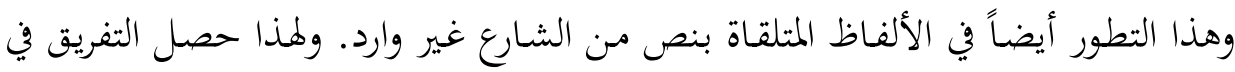

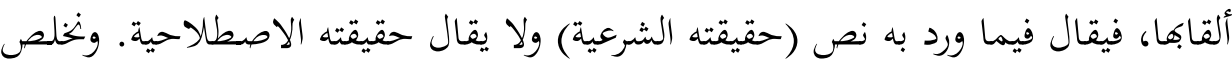

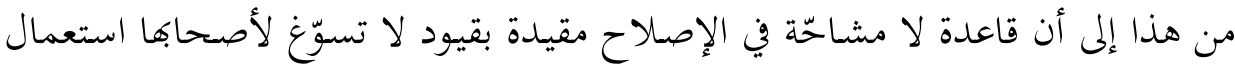
أي مصطلح خارج إطار اللغة والدلالة الشرعية والسياق التاريخي. ونستنتج مما سبق أن مصطلح الإعلام الإسلامي قد وُظظّف بعيداً عن معناه اللغوي ودلالته الشرعية وسياقه التاريخي، حتى عند المسلمين الذين صاروا يُدخِلون تحت مسماه

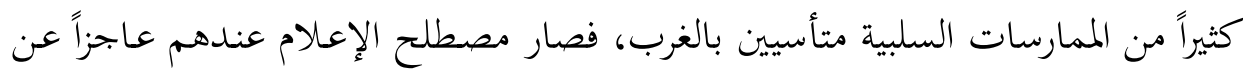
إخفاء وجهه القبيح في ظل الاستخدام المغرض له، والمسيء من طرف النازية والصهيونية والشيوعية.

ه؛ ابن قيم الجوزية، عمد بن أبي بكر. إعلام الموقعين عن رب العالمين، بيروت: دار الكتب العلمية، (991م) 
ومسن هنـا تـبرز أهميـة التأصيل الإسـلامي للعلوم الاجتماعيـة بإعـادة بنائها في ضـوء

التصوُّر الإسلامي للإنسان والبحتمع والوجود، وذلك باستخدام منهج يتكامل فيه الوحي

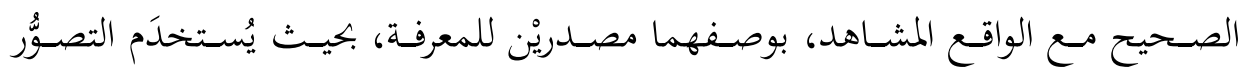

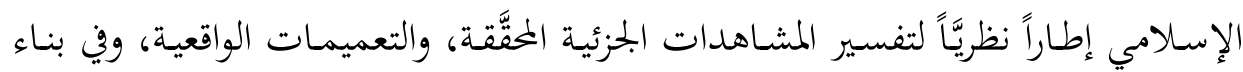

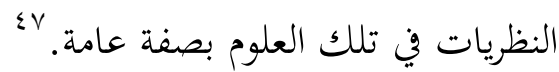

ويمكن تعريف مـنهج التأصيل الإسلامي للعلوم الاجتماعية بأنَّه: "الطريقـة المنظمـة

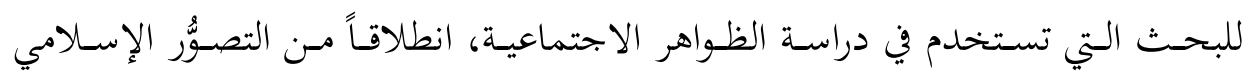

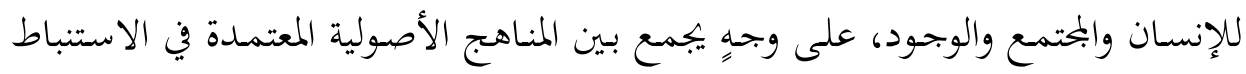

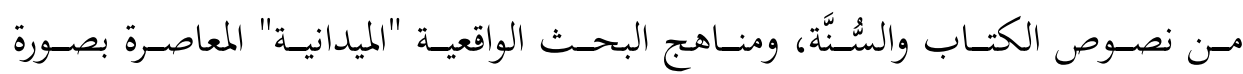

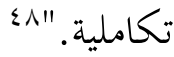

إنَّ التأصيل من حيث دلالته اللغوية يعني الوصل بالأصل، وبما أنَّ أصل كل أمرٍ وكل شيء يُرَدُّ إلى الله عزَّ وجلَّ بمقتضى المعرفة، فإنَّ مفهوم التأصيل يرتبط ارتباطاً وثيقاً بمبادئ

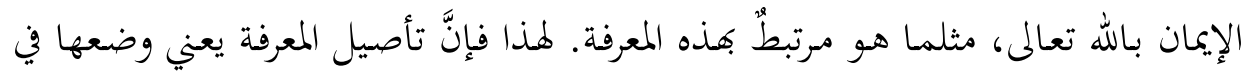

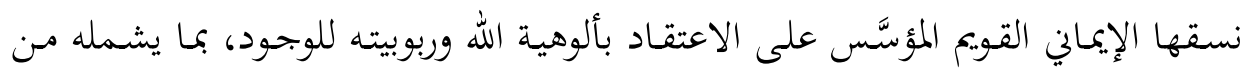

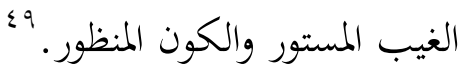

لهذا فإنَّهُ يُنظر إلى التأصيل من حيث إنَّه وصل بالأصول الدينية وبالقيم الأخحلاقية.

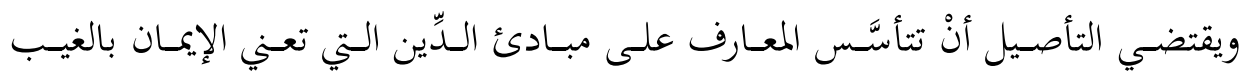

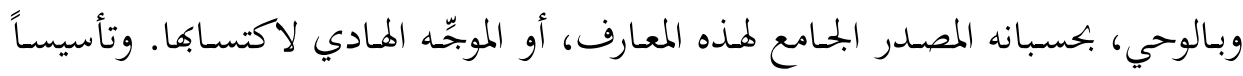

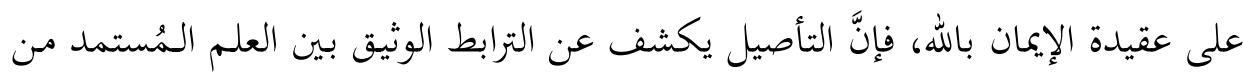

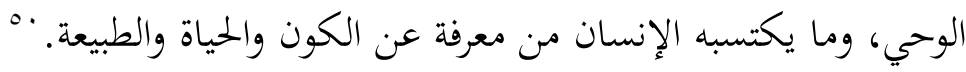

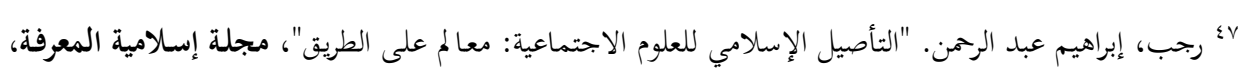

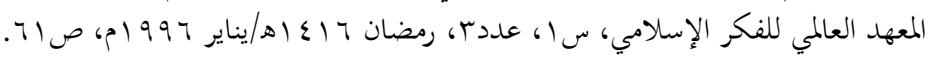

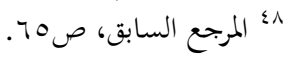

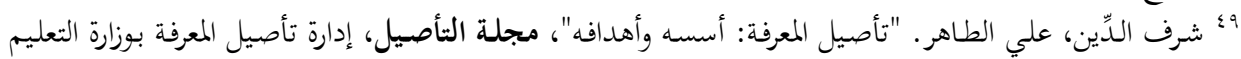

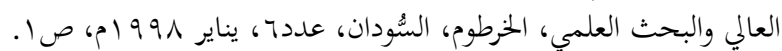

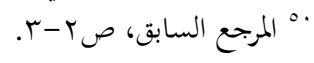


وفي ظل غياب الفهم الصحيح لإِسلام عند الكثيرين، وانتشار العلمانية التي تنادي بأنَّ العلم لا يتفق مـع التـديُّن، وأنَّ التِّانة لا تلتقي بـالتقوى، أصبحت عمليـة التأصيل أكثر إلحاحاً. '" وساد هذا الفهم عند الكثيرين مَُّّ لا يعلمون حقيقة الإسلام، فالإسلام لا يتعارض مع ما توصَّل إليه العلم الحلديث من نظريات وثوابت، حيث لا تعارض للعقل الصريح مع النَّص الصحيح.

ولـيس المقصـود بالتأصسيل إضـافة لفـظ (الإسـلامي) لكـل فـن نرتـاده، كـأن نقـول "الإعـام الإسـامي"، بـل التأصيل هو استنباط النظريـة الإسـلامية انطلاقاً مـن العقيدة الإسلامية والتشريع الإسلامي، بعيداً عن الإيديولوجيات الأخرى التي لا تعترف بالوحي

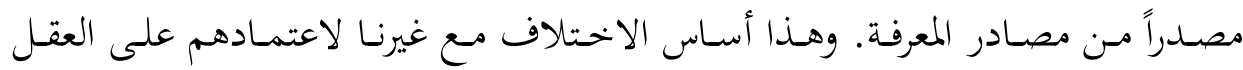
مصدراً للمعرفة، واعتمادنـا على الوحي مصدراً للمعرفة لا يتعـارض مع العقل السليم، ولهذا كتب ابن تيمية كتابه (موافقة صريح المنقول لصحيح المعقول). والأساس الثاني في الخلاف الخاص بالعلوم هو طبيعة العلوم الإنسانية اللصيقة بالإنسان، فهي وليدة البيئة الاجتماعية والنظام السائد والعقيدة التي على أساسها يبنى ذلك النظام. ويتميز الصـراع الحضـاري الإنسـاني المعاصـر، بأنه صـراع معلومـاتي إعلامي، فكري وثقافي، وهو كأي صراع بين متضادات النظم المعرفية أو البنيوية، يتألف من ثلاثة عناصر أو جوانب، تتداخل وتتساند فيما بينها بهدف حسم هذا الصراع. ro وانطلاقاً من هذا لا بدّ للأمة من وعي خاص ودقيق يجصِّنها ضد قبول المصطلحات كما هي، فبإن المصطلح يتم بتهيزه بتهيزاً خحاصاً لدى الذين يطلقونه ويزودونه بمؤثرات خاصة، فما لم يكن المتلقي له محصناً ضده فإنه غالباً ما يستسلم لإيحاءاته، كما حصل في استخدام الغرب لمصطلحات الإعلام والدعاية والتداعيات التي صاحبت ذلك. 


\section{ثالثاً: إشكالية الإعلام الإسلامي}

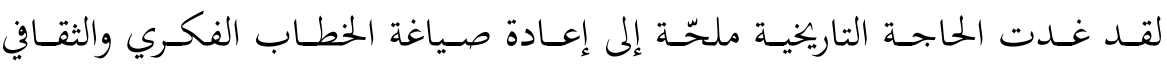

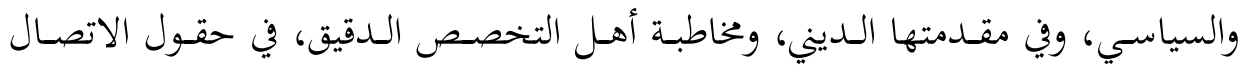

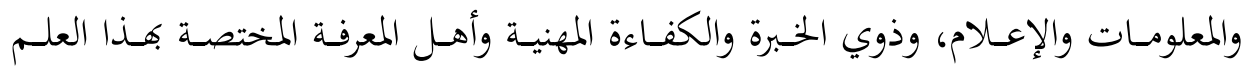

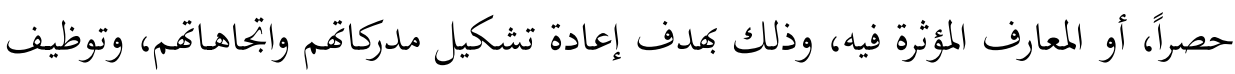
معارفهم ومهاراتم لتحقيق ذلك. هذه هي المشكلة الجوهرية في هذا الإطار.

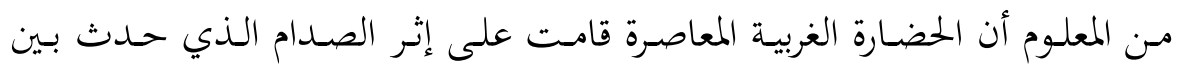

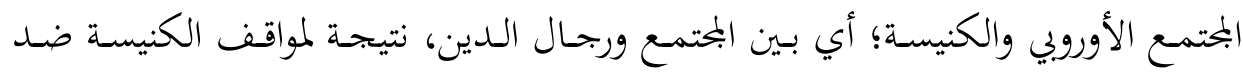

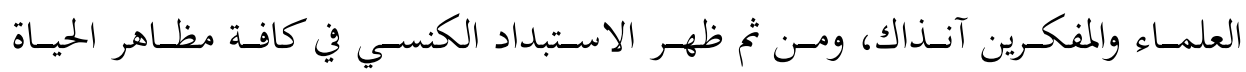
ومناشطها. وانسحب العداء ليتعدى رجال الدين المسيحي ليشمل أيّ دين، مما أحداث

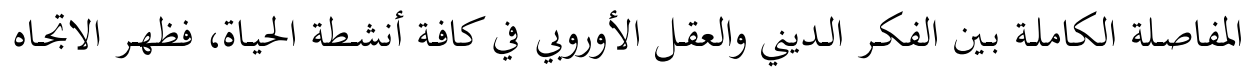

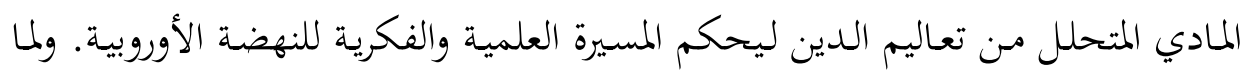

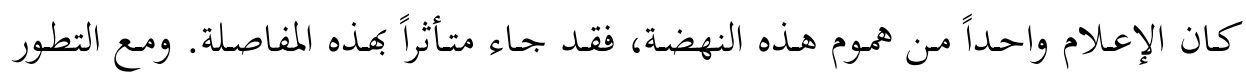

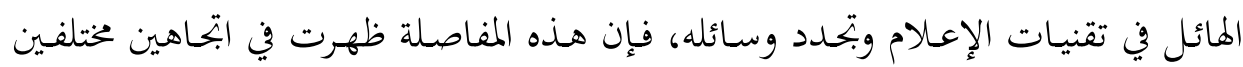
في المسيرة الإعلامية الأوروبية.

الاتجاه الأول: الإعلام المادي الدنيوي الذي ابتعد عن الالتزام بالمُثل والقيم، واتبحه

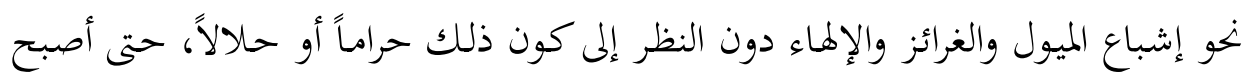

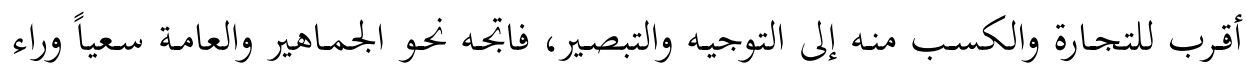

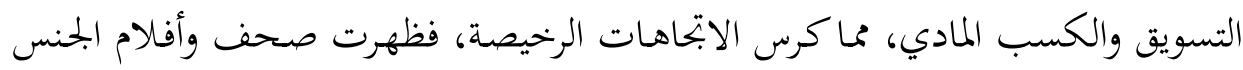
والإغراء، وقد ساعد اليهود كثيراً في دعم هذا الابتاه.

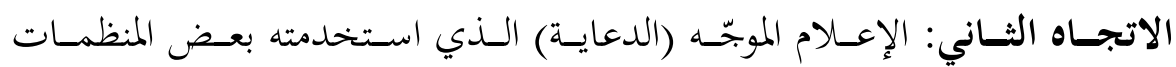

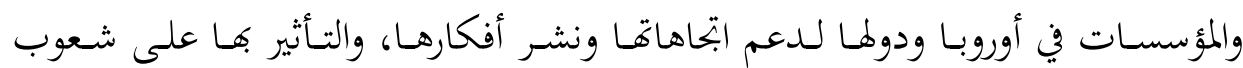

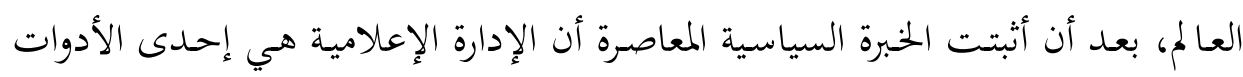

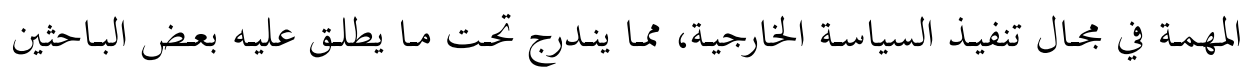


71 الإعلام الإسلامي: إشكالية المصطلح اسم (الأدوات الرمزية لتنفيذ السياسة الخارجية)، تلك الأدوات التي تهدف إلى التأثير في مفاهيم الآخرين في الوحدات الدولية الأخرى.

والمفارقة أنه في الوقت الذي بدأت فيه أوروبا هضتها الحميثة بعيدة عن الدين، كان

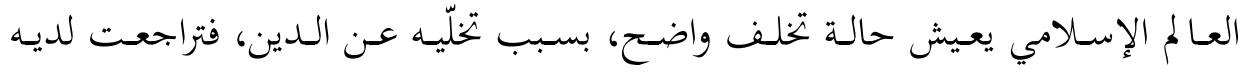

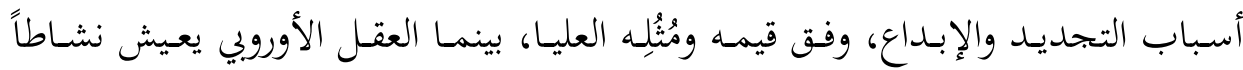

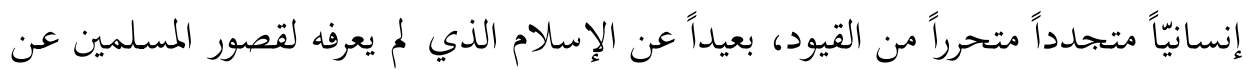
ذلك، وبذلك وقع العالم الإسلامي والعالم العربي أسير هذا الإبداع الأوروبي المتنامي. ونتج عن هذا التدفق الإعلامي الغربي، أن أصبحت المنطقة الإسلامية عامة والعالم العربي

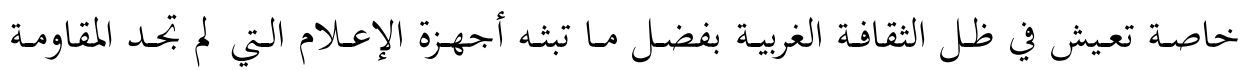

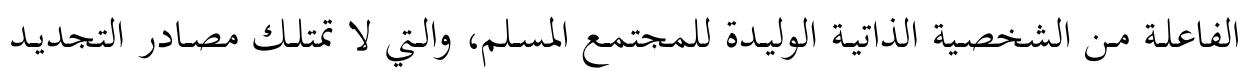
والابتكار، مما جعلها مقلدة أكثر من كوها بحددة مبدعة. أما الاتجاه التحرري المنحلّ فقد جاء بحرداً من قيم الدين، بل وقيم الإنسان المعتدل،

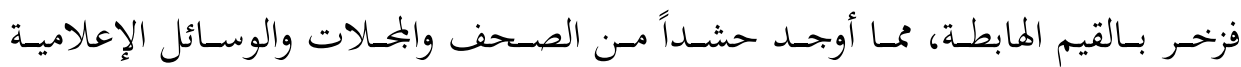

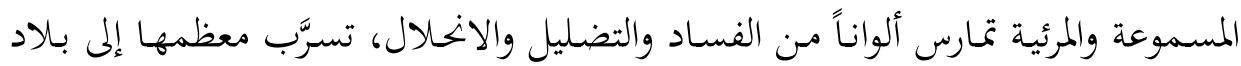
المسـلمين في غيبـة مـن الالتزام الصحيح، فأصبحت تمثل تمديداً لأبنـاء الأمـة في أعز مـا فيا تملكه من قيم ومبادئ .

أما الاتحاه الثقافي الموجّه، فقد تصدَّرته الكنيسة والجمعيات الدينية الغربية، في محاولة للتنصير بين أبناء المسلمين في البلاد النامية، وجاء مسانداً للحملات والمنظمات الكنسية التي تنتشر في معظم أحخاء العالم الإسلامي في إفريقيا وآسيا على وجه الخصوص، امتداء إداداً

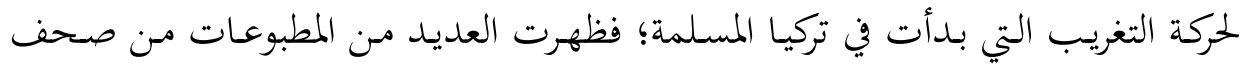
وبحالات ونشرات، ثم استخدمت الإذاعة على المستوى القومي والشعبي، حيث استقلت بعض الميئات الدينية النصرانية بمحطات خاصة، كما حدث في البرتغال وإيطاليا وهولندا. وواضح مما تقدم أن الإعلام يعدّ من أهم الأسلحة المستخدمة في الصراع الحضاري،

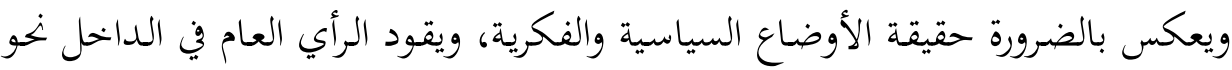




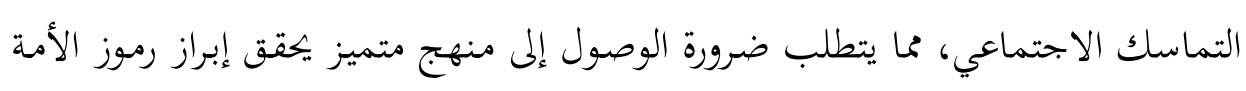
وحمَلة الفكر فيها، مع افتراض درجة عالية من النماعي النقاء والوضوح.

وتظهر الأهمية أكثر عندما يكون للأمة فكر وعقيدة تسعى لنشرها وحمايتها عن

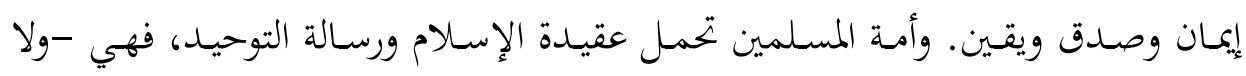

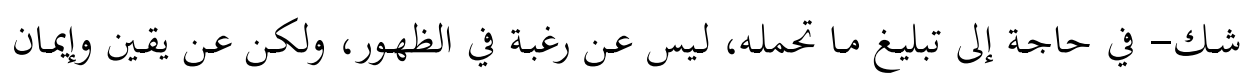

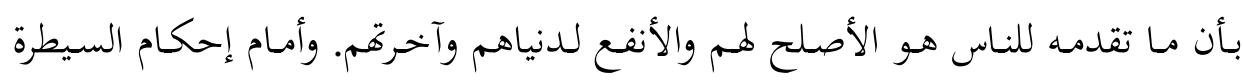

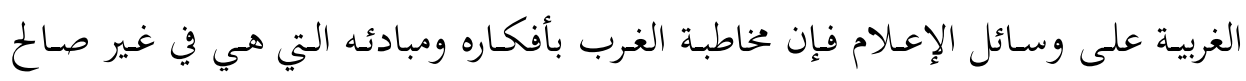
المسلمين، تتم مباشرة لشعوب العالم الثالث، وضمنها الشعوب الإسلامية، مما أثر كثيراً

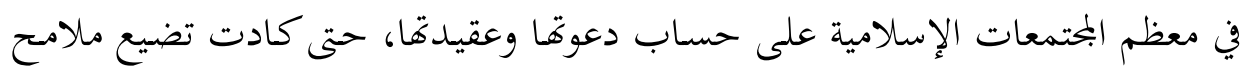

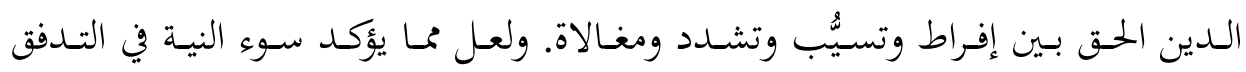

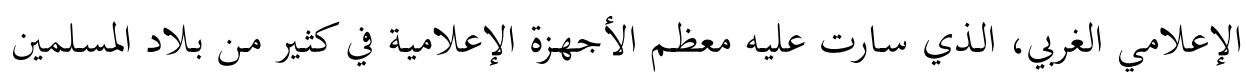

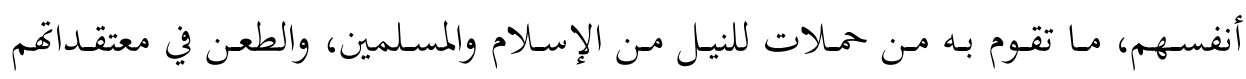

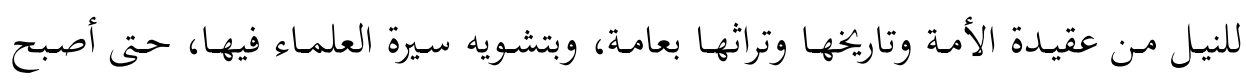

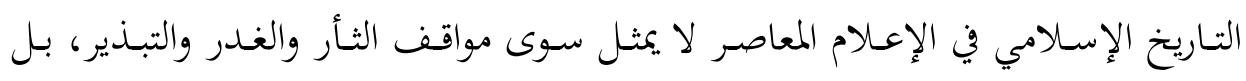

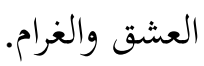

\section{رابعاً: الإعلام الإسلامي بين الواقع والمأمول}

انسبرى فريـق مـن البـاحثين الملتـزمين لإيجـاد إعـلام متميـز تحـت مســمى (الإعـلام

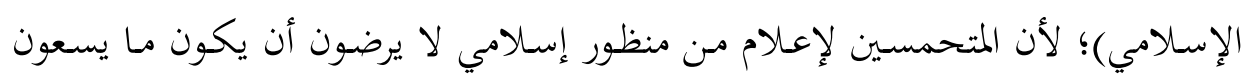

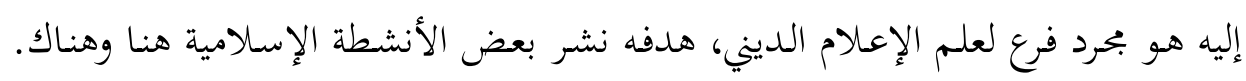

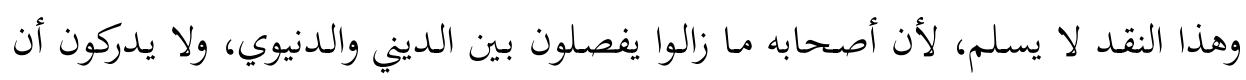

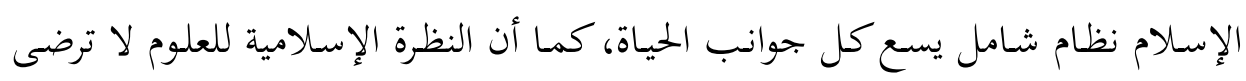

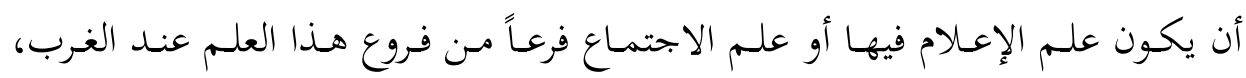
لاختلاف المناهج والأهداف والتصورات المعرفية عند كل منهما. 
وقد حصر أصحاب هذا الاتجاه الإعلام الإسلامي في أروقة ضيقة، وروافد محدودة تمثلت في بحلات وصحف، وبرامج تلفزية وإذاعية إسلامية، لتتطور إلى قنوات تحمل صوراً

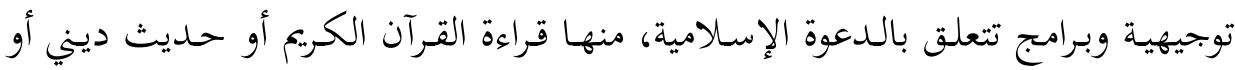

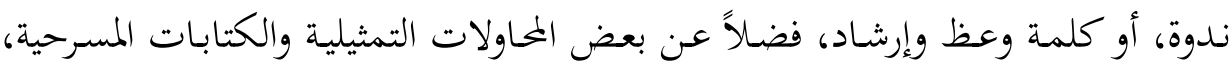
غير أها اتسمت بقلة الإمكانات المادية نتج عنها ضعف في الإخراج وسوء الطباعة، مما جعلها غير قادرة على الوقوف في مواجهة المنافسة مع غيرها من الوسائل الحديثة. لكنهـا في النهايـة صـدرت تحت مسـمى البرامج الدينيـة والصفحات الإسـلامية في الصحف، بما كرس مفهوم المفاصلة بين ما تقدمه وسائل الإعلام من مواد عامة متنوعة،

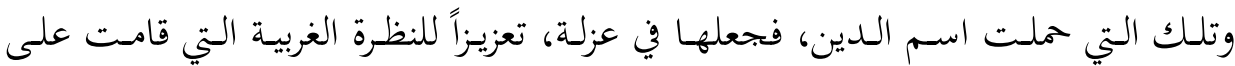

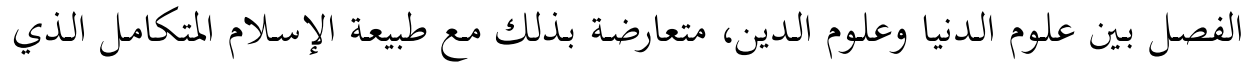
يجعل الحياة كلها عبادة .

ومما زاد من عزلة هذه البرامج التي قدمت تحت مظلة الدين، أها لم تحظ بنصيبها من الفـن الإعلامسي في التجديـــ والتسـويق، وظهـرت غريبـة، وسـاعد علـى غربتهـا: تــدني

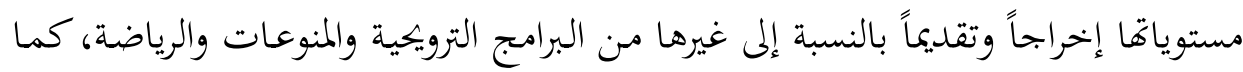
أفها - في نظري- تمثل نظرة جزئية للإعلام، ورؤية قاصرة لا تفي بما نصبو إليه من رؤية شاملة لإعلام شامل لكل البشر، يتبنى التصور الإسالامي والرؤية الإسلامية. وقـد عـارض بعضهم إضـافة صفة (الإسـلامي) الذي لا أرى - في مـذهبي- ضـرورة لإضـافة لفظ الإسلامي إلى الإعلام، لأنه لا معنى لتخصيص هـذا الفرع من فروع المعرفة بالإسلام. ترى هل معنى ذلك أن فروع المعرفة الأخرى التي لم توصف بالإسلامية كافرة؟ لأننا لم نقرأ يومـاً عن إعـام مسيحي أو إعلام يهودي، وما استعمل العلماء المسـلمون عبر العصور لفظظ الإسـلامي كإضـافة لأي علـم مـن العلوم التي درسوها. ومـع تسـليمنا بوجاهـة هـا الاعتراض وإقراره إلا أنه لا مـانع في الوقت الحاضـر مـن استعمال مصطلح

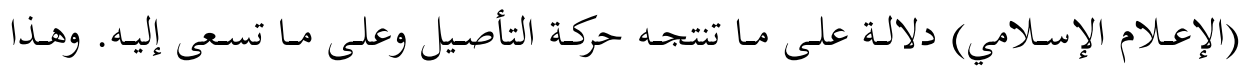

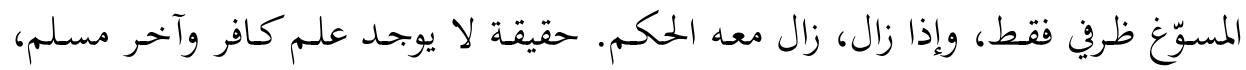


وإنما توجدل نظريات صائبة وأخرى خاطئة، والأصل في العلم أن يكون صواباً متفقاً مع الشريعة، فإذا عارضها فقد انتفت عنه صفة العلمية، وانحط إلى رتبة الجههل أو الضلال

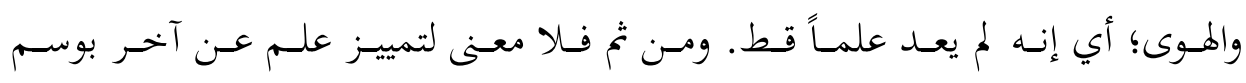

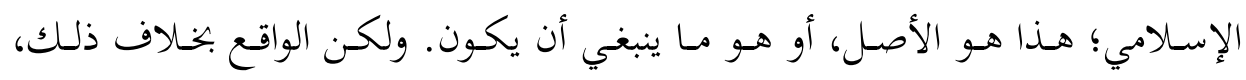
فنحن بحد تخريفاً أخذذ اسم العلم بل علوماً مبنية على تصورات منحرفة معارضة للشريعة الإسلامية، ومع ذلك لم يسلبها ذلك صفة العلمية عند الكثير، بل إذها تدرّس في بـاد بلاد المسلمين ودور علمهم بصيغها المنحرفة، وبما أن التصور البـديل مـا زال مفقوداً والتصور

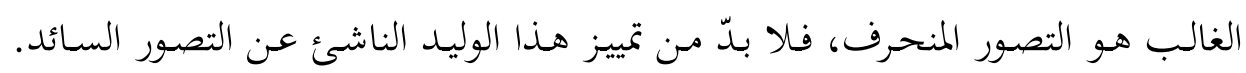
وهذه التسمية ليس هدفها تمييز تصور عن آخر فحسب، بل وظيفتها الثانية أها إصبع

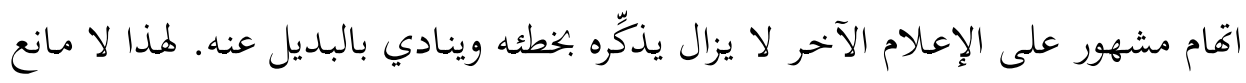

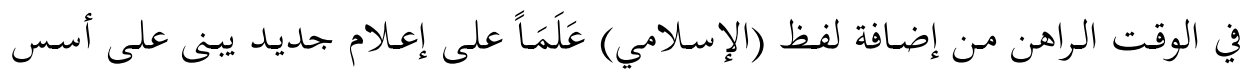
إسلامية.

ومن هنا تظهر الحاجة إلى إعلام ملتزم يحمل الإسلام بكل مفاهيمه وشموله، مستقلاً

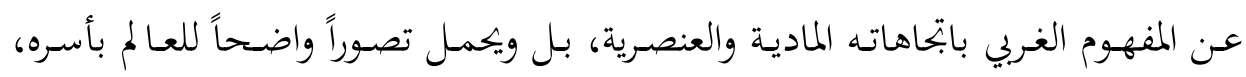
حتى لا تقوم تلكك الازدواجية بـين مـا هـو برنـامج ديني أقرب إلى الجمـود منه إلى الحركة

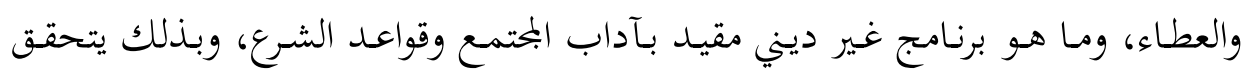

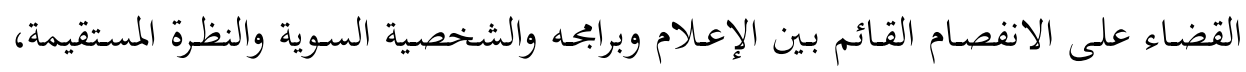

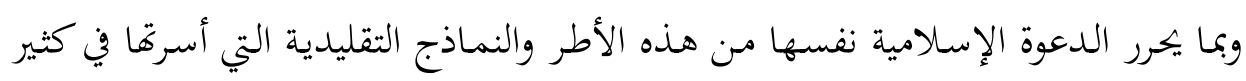

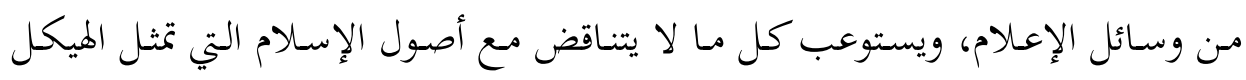

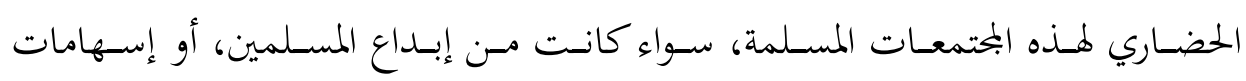

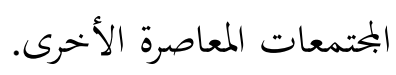

وهـو يقـوم على أخـذ وقبـول إسـهامات البحتمعـات الأخــى في بجـال علـم الإعـلام

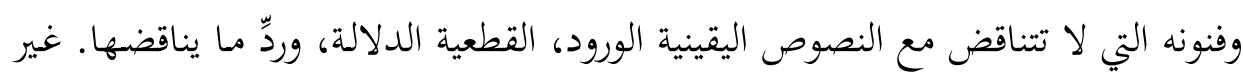

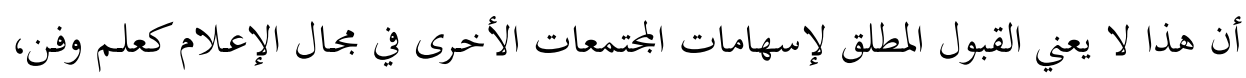


علي العاتري الإعلام الإسلامي: إشكالية المصطلح

بل يعني أن معيار الأخذ أو الرفض في بحال علم الإعلام هو التجربة والاختبار العلميين. ومعيار الأخذ أو الرفض في بحال فن الإعلام هو مدى صلان الاحية الأنماط المختلفة للعملية الإعلامية لواقع المجتمعات المسلمة، والمشكلات التي يطرحها هذا الواقع. ونعني بتأصيل الإعلام وصل المصطلح بالأصول الشرعية والقيم الأخلاقية. ويقتضي ذلك أنْ تتأسَّس المعارف على مبادئ الشرع، التي تعني الإيمان بالغيب وبالوحي، بوصفه المصدر الجحامع لهذه المعارف، أو الموجِّه الهادي لاكتسابه. ومبـادئ الـوحي تشــل : العقائـد، والمعـاملات، والأخهـلاق. وتأسيسـاً على عقيـدة الإيمان بالله، فإنَّ التأصيل يكشف عن الترابط الوثيق بين العلم المُستمد من الوحي، وما

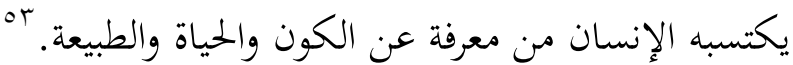

إنَّ عملية التأصيل في عصر العولمة الذي يتَّسم بصراع الحضارات والاختراق الثقافي،

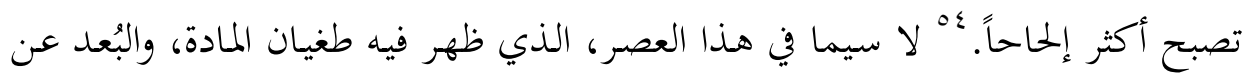
القيم الإسلامية الحقَّة، وغاب الفهم الصحيح للإسلام عن الكثيرين، وانتشرت العلمانية

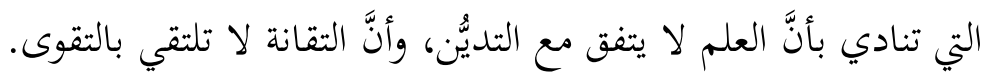
وانطالاقاً من أن الإسلام منهج كامل متكامل يسع جوانب الحياة كلها، اعتقد أننا

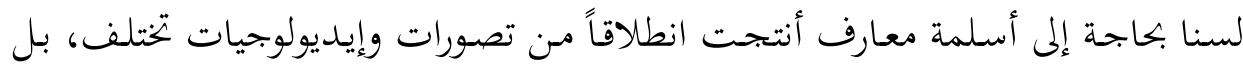
تناقض معتقداتنا وتصوراتنا، ولسنا مضطرين إلى البحث عن أصول لما أنتجه الغرب من إن

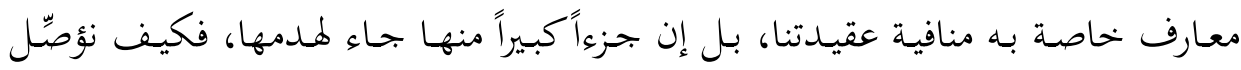
لفكر أساسه الإلحاد وتاليه العقل؟ كيف نؤصِّل لفكر قائم على نشر الرذيلة والفساد. والشرع الإسلامي المقدس طالما أنه استمد أحكامه من القرآن الكريم الذي فيه تبيان لكل شيء، ومن ضمن هذه الأشياء العلوم الإنسانية، فلا بدّ عندئذ من أحكام شرعية يُلتزَزُ بها، تخص كل العلوم الإنسانية. فالرؤية الإسلامية النابعة من القرآن والسنة تعتمد على تطبيق المنهج الإسلامي في حركة المجتمع الاقتصادية والسياسية والثقافية، التي تأتي 


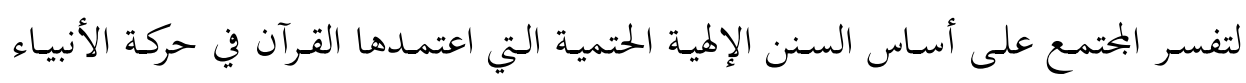
والمصلحين، في مقابل المدرسة الشيوعية والرأسمالية.

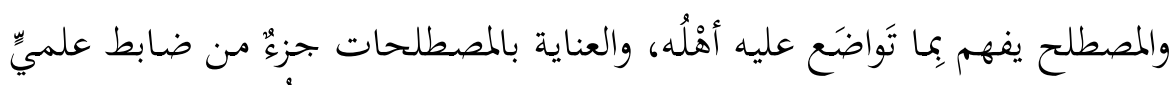

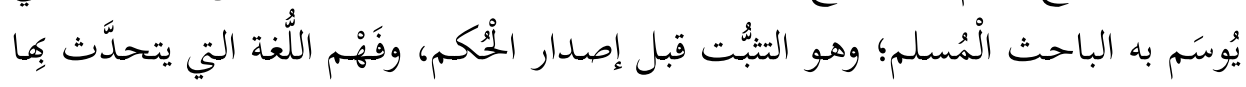

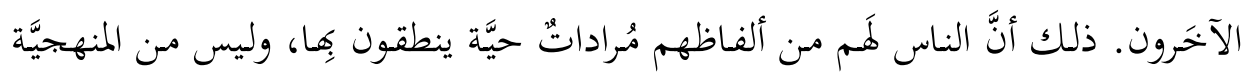

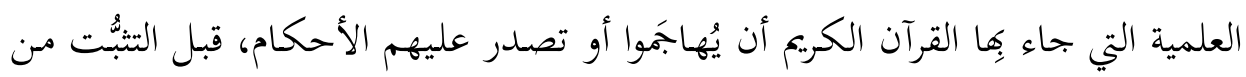

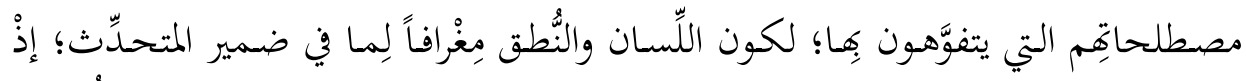

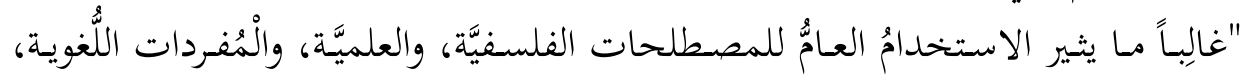

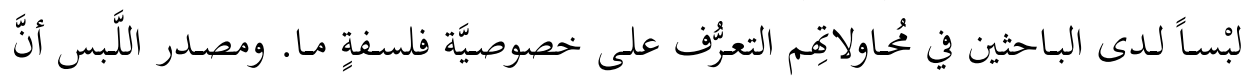

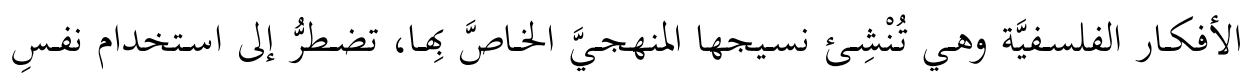

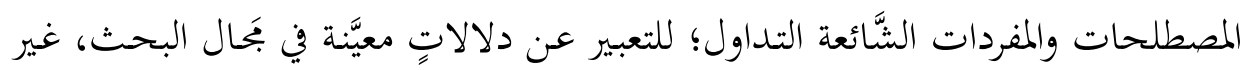

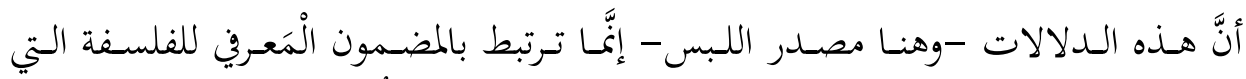

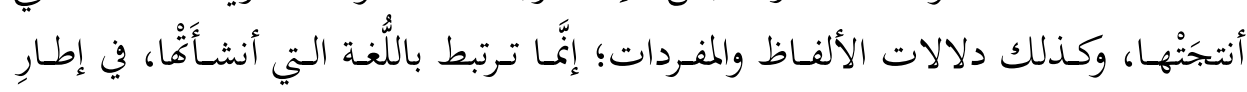

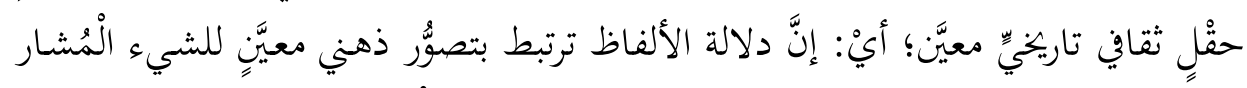

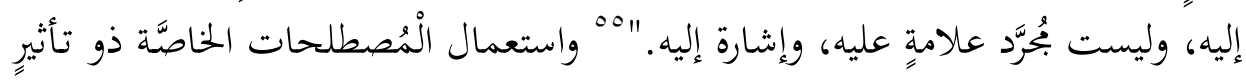

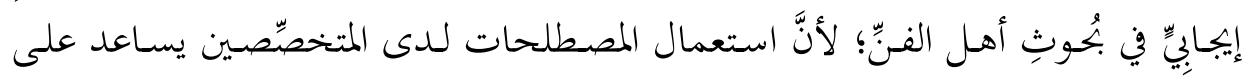

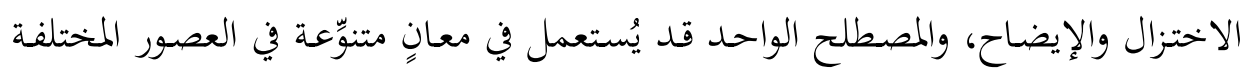

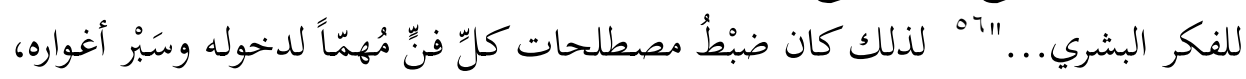

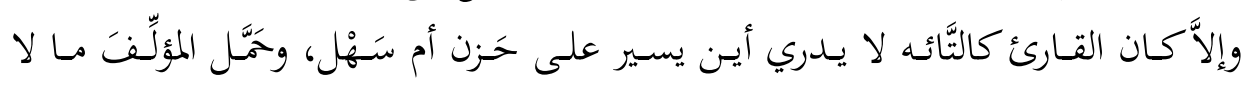

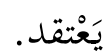

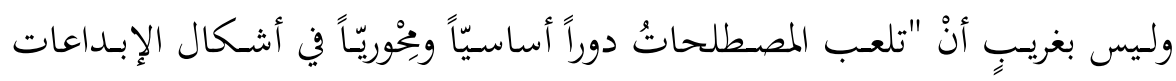

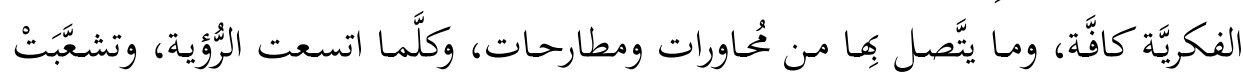

• حاج حمد، عمد أبو القاسم. منهجيَّة القرآن المعرفية، أسلمة فلسفة العلوم الطبيعيَّة والإنسانية، بيروت: دار

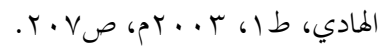

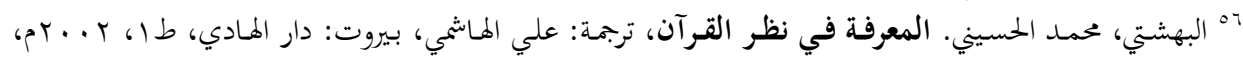




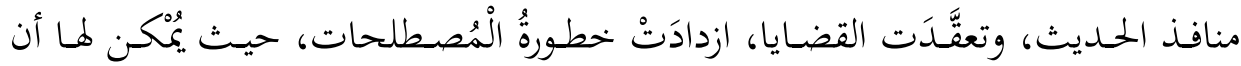

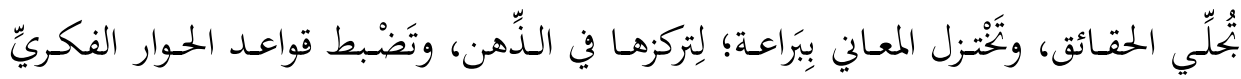

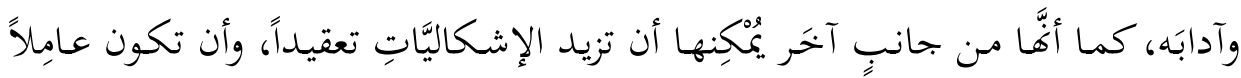

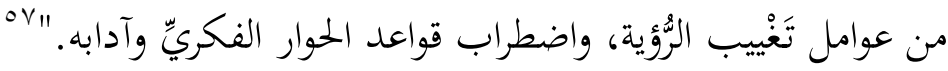

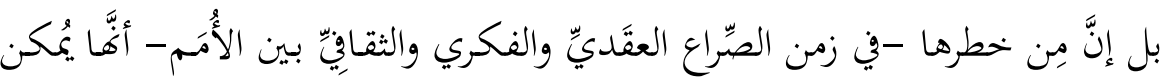

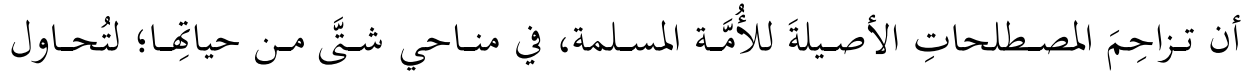

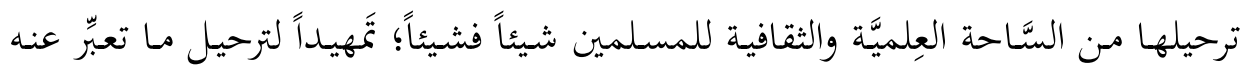
من معتقَدِ، أو فكر، أو خلُقِّ إسلامي أصيل.

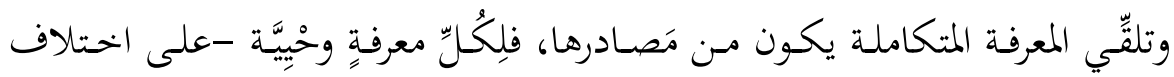

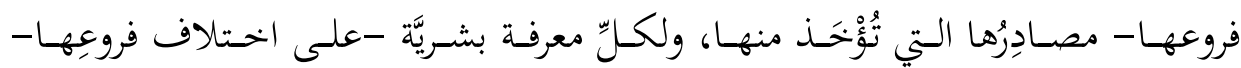

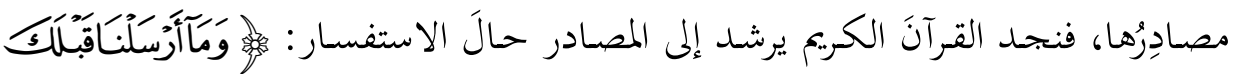

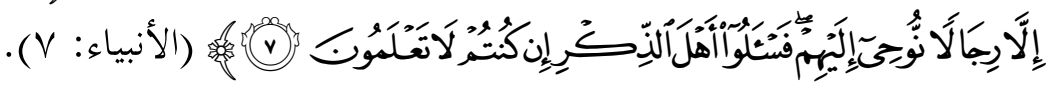

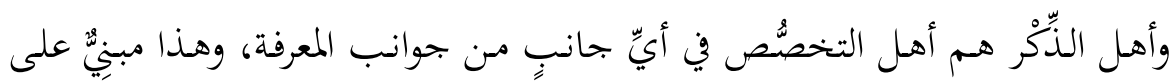

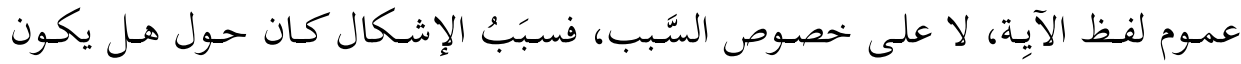

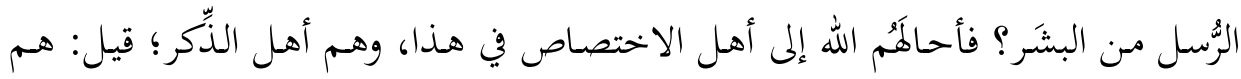

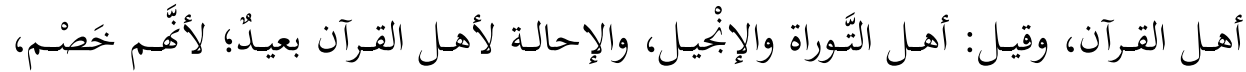

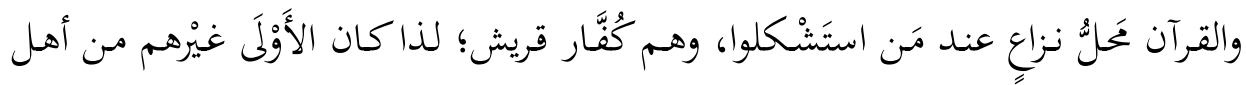

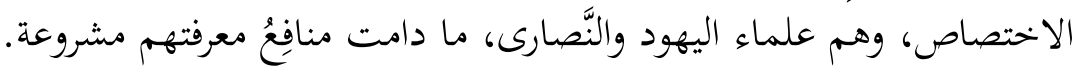

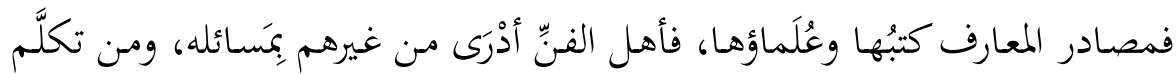

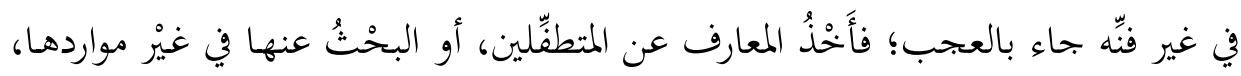

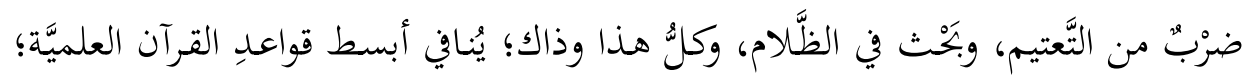

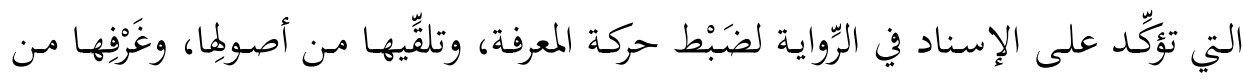

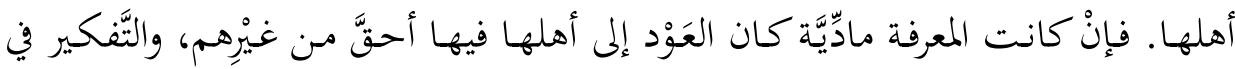




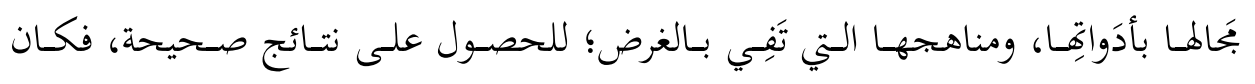

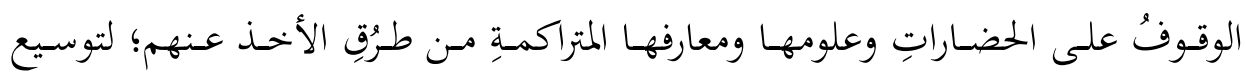

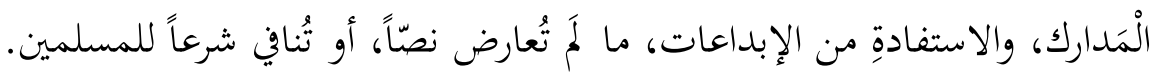

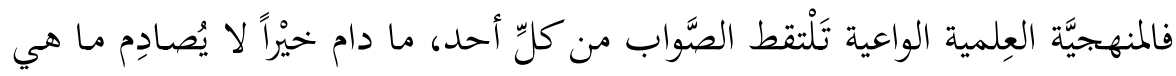

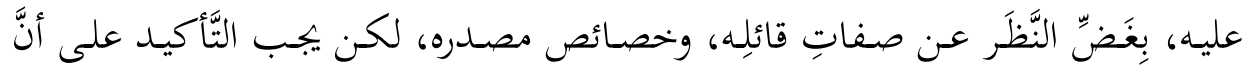

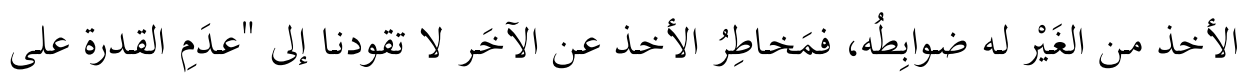

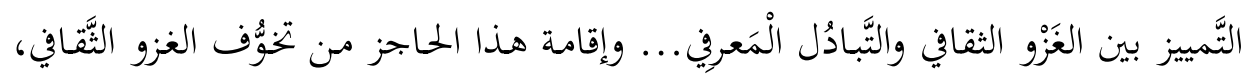

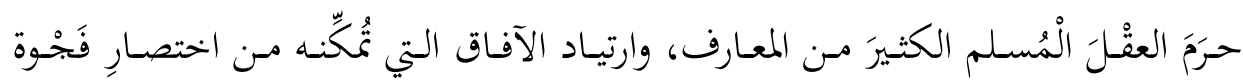

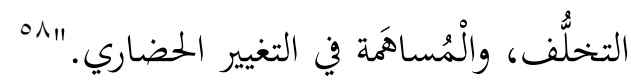

\section{والنظرة الإسلامية للإعلام هي نظرة تنطلق من:}

ا ـ منطلق العقيـدة: التي تقـوم على فطرة البشـر، وتستقيم مـع متطلبـات الحيـاة

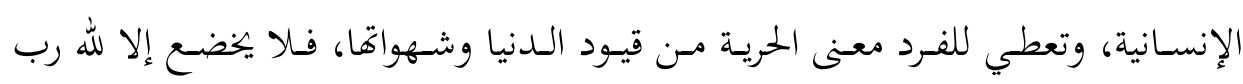

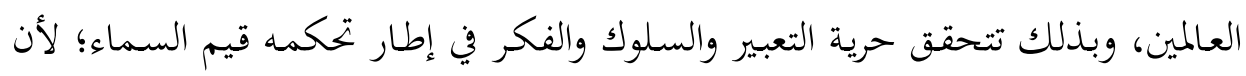
الهدف هو إرضاء الله تعالى وليس المكسب الدنيوي فقط. r. منطلق العلم: الذي هو طريق المعرفة، فقد جاءت آيات الله سبحانه واضحة،

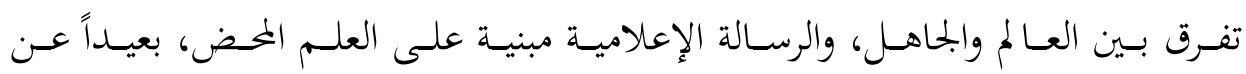

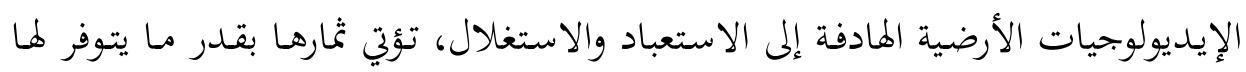
من علم صحيح ومعرفة واضحة لا يختلف عليها العقلاء. r. العدل: فالإعلام الذي نصبو إليه إعلام عادل، يوصل المعلومات والأخبار لكل

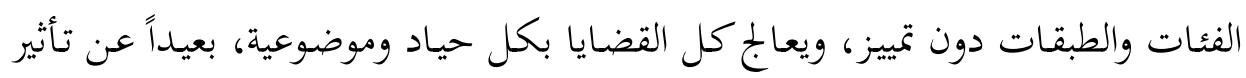
السلطة أو الجحاه أو المال. - مات دون 
$79 \quad$ علي العاتري الإعلام الإسلامي: إشكالية المصطلح

ع. منطلـق الأخهـاق: وهـي سمـة الإنسـانية الفاضـلة ودسـتور التعامـل بــن البشــ،

فيصدر الإعلام عن نفْسِ تعرف الصدق والأمانة والطهارة عن عإيمان وامتثال، وليس عن تقليد ومحاكاة.

هـ منطلق الإنسانية: بما تحمله من معاني الرحمة والتكافل والتعاطف، وما تعنيه من أخوة بين البشر ورغبة في التعايش السلمي، والتعاون المثمر البنّاء، فالإعلام الذي يحمل لرحل سمات الإنسانية هو أقدر من غيره على التأثير والتجاوب .

7. منطلقق الجمـال: يتطلـع إلى حسـن العـرض وعفـة الطـرح، ورفعـة الـذوق، وسمـو الآداب، بما يمقق الارتياح النفسي، والوئام الاجتماعي، والأمن الإنساني. V. منطلـق المصـلحة العامـة للأمـة: فهـو إعـاملام بنّاء، يجـــص على أمـن المجتمـع واستقراره، بعيداً عن الإشـاعة المغرضـة والتحريض الهـام ضــ فئـات المجتمع وقادته، بـل دعوة صادقة ذات مسؤولية مشتركة تحفظ كيان الأمة وتنشر الخير للناس جميعاً. إن صسياغة نظريـة إعلاميـة علميـة مدروسـة ومتكاملـة الأبعـاد ومتناسـقة التخطيط

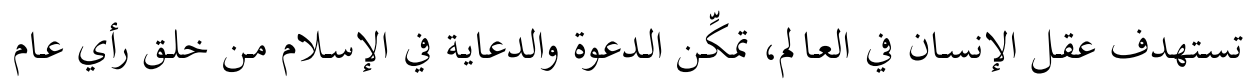
عالمي مناصر ومؤيد للإسلام، وتمكِّن من تحييد العناصر الحاقدة التي تناصبه العداء، تحتاج إلى استراتيجية عليا.

خاتمة:

تستوجب آلية هذه المنظومـة الإعلامية وتأثيرهـا الاستراتيجي، دراسة مفصلة لجملة مـن العلوم والمعارف، يقف في مقـدمتها علمم الاتصـال والمعلوماتية، الذي يضبط الصـلة

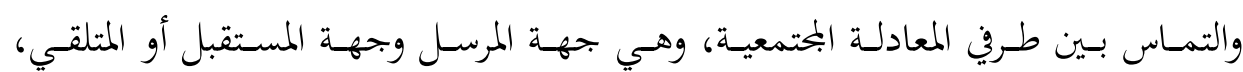
وتتشكل مادته مس خهلال رسالة الإعلام والدعاية والخطاب المتضمن فيها، ونقلها عبر قنوات الاتصـال، فتكتمل بذلك حلقـة أو خطة الاتصـال، وتشـمل هذه المنظومـة جميع 
الوسائل المعلوماتيـة، المقرووة والمسـموعة والمرئية، والمنقولة عبر شبكات المعلومات المحلية والدولية.

وتؤسس معلومات الرأي العام بمجموع مصادرها، الحقائق الساندة لدراسة مرتكزات "الاسـتراتيجية الوطنيـة العليـا"، والمقـدمات لنتائجهـا، باستقراء خيـارات البـدائل وتحليلها وتقويمها، مـن خهلال مناقشـة حزمـة مـن العوامل، وتثبيـت نقـاط القوة والضعف إزاءكل منها، ومن بين هذه العوامل، الموارد الوطنية المادية والبشرية أو السكان، والكلفة وتأثير الخيـارات المتاحسة، ومقارنـة المزايـا والتحديــات لكـل منهــا، والبيئـة السياسـية الإقليميـة

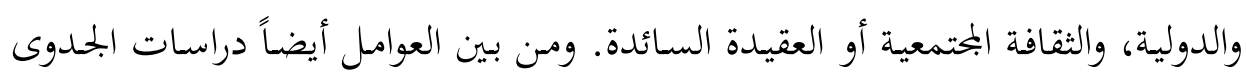
الاقتصادية للمشاريع الاستراتيجية.

وتأصيل مصطلح الإعلام، يعني: العودة به إلى أسسه وقواعده الشرعية التي تحكمه في ضوء القرآن الكريم، والسُنَّة النبوية المطهرة، وهو البحث عن أصوله الشرعية التي يستند إليها.

وملا كانت الدعوة الإسلامية هي قدر أمتنا الإسلامية، فقد أصبح لزاماً عليها أن

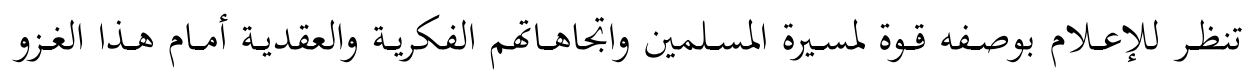
الغربي، الذي لا يمثل النموذج المطلوب وفق الهدي الإسلامي، مما يتطلب محاولات جادة لتأصيل الإعلام، ليكون عنصراً فاعلاً في مسيرة الدعوة الإسلامية.

وإذا أردنا النجاح في إعداد خطط إعلامية في مستوى التحديات ومواجهة الإعلام المضـاد للإسهلام، لا بُدَّ مـن الرجوع إلي هدي الإسلام لاستلال نظريـة إعلامية منضبطة

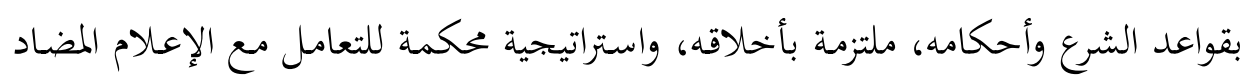

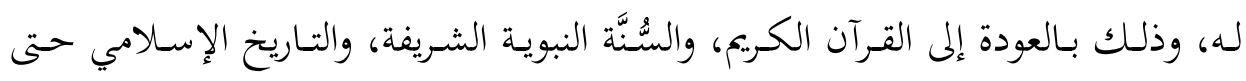

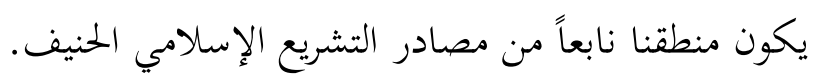

9॰ الشيرازي، محمد الحسيني. المرجعية الإسلامية: رؤى في الأساليب والأهداف، بيروت: دار العلوم، ع ؟ اهـ، 
VI علي العاتري الإعلام الإسلامي: إشكالية المصطلح

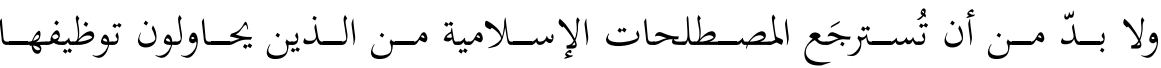
واستعمالها في غير موضعها، ومسن أمثلة ذلك مـا شاع مـن استثمار بعض المصطلحات كالإعلام، الذي هو في الاستخدام الإسلامي الدقيق دعوة إل خحير بني الإنسان، وتبليغ

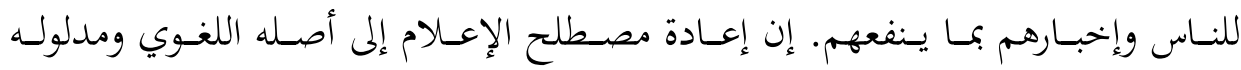
الشـرعي وسياقه التـاريخي، يكشف كثيراً مـن الزيف والتشـويه الذذي علق بـه مـن جـراء الاستخدام المغرض له لدن النازية والشيوعية والصليبية.

كمــا يتطلـب ذلـك اعتمـاد الطرائـق الملائمسـة لتطـوير وبنـاء الاسـتراتيجية الوطنيـة للإعـالام والإعـام المقابـل، والتخطيط لمرتكزاهـا في ظل الأهـداف والمضــامين والأدوات

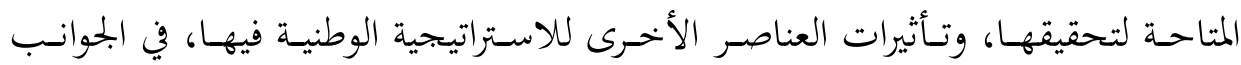
السياسية والاقتصادية والاجتماعية والدفاعية الأمنية.

وتظهر الحاجـة إلى إعـلام ملتـزم يحمل الـدعوة الإسـلامية بكل مفاهيمها وشمولهـا، مستقلة عن المفهوم الغربي بابجاهاته المادية والعنصرية، حتى لا تقوم تلك الازدواجية بين ما هو برنامج ديني أقرب إلى الجمود منه إلى الحركة والعطاء، وما هو غير مصنف في خانة الديني ولكنه مقيد بآداب المجتمع وقواعد الشرع، وبذلك يتم القضاء على الانفصام القائم بين الإعـام والدعايـة وبرابجهما، والشخصية السوية والنظرة المستقيمة، وبما يحرر الدعوة والإعـام الإسلامي نفسه مـ هذه الأطر والنماذج التقليدية، التي هي عليها في كثير من وسائل الإعلام، للاستفادة من مميزات عدة تتميز بها هذه الدعوة الإسلامية، نذكر منها: أولاً: الطبيعة الإعلامية للدعوة الإسلامية. ثانياً: قدرة الدعوة الإسلامية على مئى استيعاب الوسائل المتاحة. ثالثاً: تمايز المسيرة الإسلامية ومنطلقاها. والتنظير الإعلامي مـن وجهة نظر الإسـام، كما هـو الشـأن في المعارف الأخـرى، بحاجة إلى تضافر جهود كافة الباحثين المخلصين والغيورين، لإيجاد نظرية مستقلة مستمدة مـن الأصسول الشـرعية، وتسـتوعب كل مـا توصـل إليـه العقل السـليم والمنطق القويم مـن إبحازات، بغض النظر عن المكان والزمان. 
ويمكن الوصول إلى شيء مما نصبو إليه من خلال التوصيات الآتية:

أولاً: التخطـيط الإعلامسي: ونعـني بـه وضـع نظريـة إعلاميـة تحـدد أسـس الإعـلام

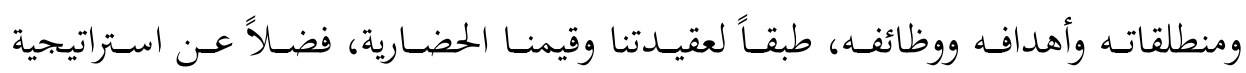
إعلامية تحدد الخطة الإعلامية، والأسلوب الإعلامي الذي يمدد المنهج الإعلامي.

ثانيـاً: تحديـد الأهـداف: أن تكـون أهـدف الإعـلام واضـحة شـاملة مسـتوعبة لكل الفئات والطبقات ولكل الشعوب والأجناس، وترمي إلى تحقيق التوازن بين مصلحه الفرد ومصسلحه الجماعـة، والمصـلحة الخاصـة والمصـلحة العامـة، وتنشـــ تحقيـق السـلم والأمسن العـالميين، والعدالـة الاجتماعيـة العالميـة. وكـل إعـلام يهـدف إلى تحقيـق المصـلحة العامـة للبشرية يتبنى الحق ويدافع عنه هو (إعلام إسلامي) وإنْ لمُ يضف إليه كلمة "الإسلامي". ثالثـاً: التنظيم: مـن خهلال تأكيـد دور الدولـة في إدارة الإعـلام كنائسب ووكيـل عـن

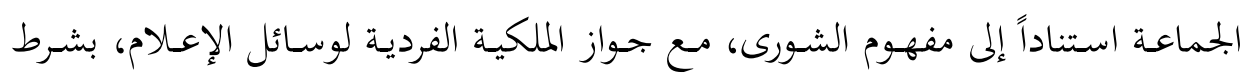

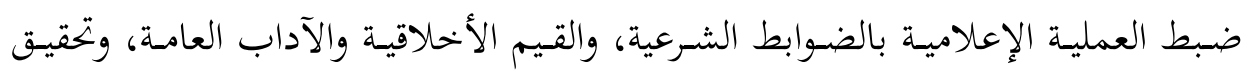
المصلحة العامة.

رابعاً: الاستفادة من إسهامات الأمهم: الاستفادة مـن إسهامات المجتمعات المعاصرة

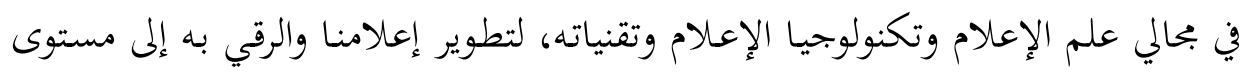
مخاطبة الآخرين والتأثير فيهم. خامساً: إرساء مبدأ الحرية الإعلامية: العمل على توسيع هامش الحرية الإعلامية، دون حجر على شخص أو فئة أو طائفة، بشرط التقيد بالضوابط الشرعية والأخلاقية،

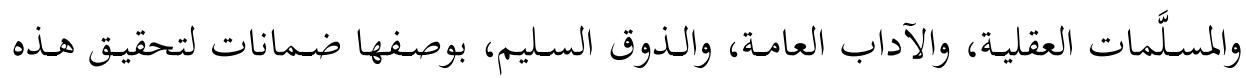
الحرية لا معوقاً لما. وهذا ما نريده ونروم تحقيقه وإنْ لمُ نربط لفظ الإعلام بالإسلام. سادساً: إبراز تأكيد الهويـة الوطنية: لا بـدّ من أن يؤدي إعلامنـا دوراً بـارزاً في إبراز

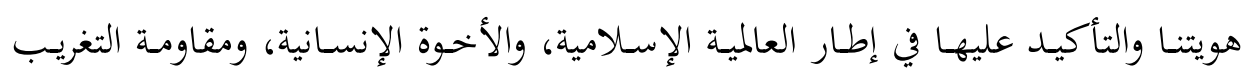


علي العاتري

الإعلام الإسلامي: إشكالية المصطلح

والانسـلاخ والتفسخخ، والتصـدي لكل محاولات السيطرة على بني الإنسـان واستغلاله،

مهما كان مذهبهم أو جنسهم أو لوغهم.

سابعاً: الالتزام بالصدق: إيصال المعلومة أو الخبر بكل أمانة، وإلى كل إنسان بغض

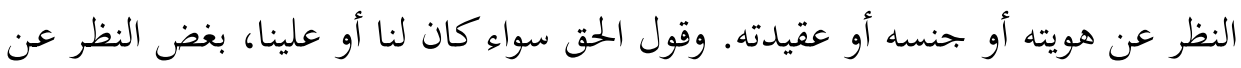

المكاسب العاجلة أو الأغراض العارضة، التي يمكن أن يحققها التزييف والتحريف.

ثامناً: الموضوعية والحياد: طرح أي مشكلة ومعالجتها بكل موضوعية وحياد، وردع

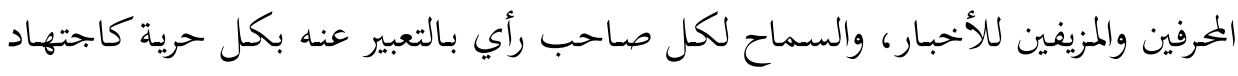

مسؤول يتحمل تبعاته. 